\title{
How Loud Is Too Loud? Competing Rights to Religious Freedom and Property and the Muslim Call to Prayer (Adhan or Azan) in South Africa ${ }^{+}$
}

\author{
Najma Moosa
}

check for updates

Citation: Moosa, Najma. 2021. How Loud Is Too Loud? Competing Rights to Religious Freedom and Property and the Muslim Call to Prayer (Adhan or Azan) in South Africa Religions 12: 349. https://doi.org/ $10.3390 /$ rel12050349

Academic Editor: Waheeda Amien

Received: 6 February 2021

Accepted: 8 May 2021

Published: 14 May 2021

Publisher's Note: MDPI stays neutral with regard to jurisdictional claims in published maps and institutional affiliations.

Copyright: (C) 2021 by the author. Licensee MDPI, Basel, Switzerland. This article is an open access article distributed under the terms and conditions of the Creative Commons Attribution (CC BY) license (https:// creativecommons.org/licenses/by/ $4.0 /)$.
Department of Private Law, University of the Western Cape, Private Bag X17, Bellville, Cape Town 7535, South Africa; nmoosa@uwc.ac.za

+ I acknowledge, with thanks, the reviewers for their insightful contributions which has enhanced the final version.

Abstract: This article approaches the position of the call to prayer (adhan or azan) in South Africa from the perspective of both legislation and case law. Although only an unamplified adhan has religious status in Islam, Muslim religious authorities (ulama) have since the twentieth century also approved of, and permitted, an amplified adhan. The adhan has been rendered in both forms from South African mosques (masjids) for some 223 years. However, the unamplified adhan has recently come under the legal and judicial spotlight when the volume of its rendering by human voice was restricted. In August 2020, after prior attempts at municipal level and mediation had been unsuccessful, a high court in KwaZulu-Natal, South Africa, ruled that the sound of the unamplified adhan emanating from a mosque located on the premises of an Islamic institution (madrassa) in the city of Durban should not be audible within the house situated on nearby property belonging to a Hindu neighbor. Wide media coverage reported that the ruling was publicly decried and met with criticism. The Madrassa lodged an appeal in September 2020 and the matter is ongoing. The High Court's decision is binding in KwaZulu-Natal, a province where Hindus, as a religious minority, are concentrated. The article highlights that although the decision is not binding on similar courts in other provinces, its outcome may yet have far-reaching consequences for the adhan as a religious and cultural heritage symbol, and for religious symbols generally, because similar complaints have been lodged, albeit against amplified adhans, against several mosques located in major cities (Cape Town and Tshwane) of two other provinces where Muslims, as a religious minority, are largely concentrated. The article examines the adhan in the context of competing constitutional rights to religious freedom and property (neighbor law) in South Africa. The article proffers some recommendations for the way forward in South Africa based in some instances on the position of the adhan in several countries. It concludes that, ultimately, unamplified, unduly amplified and duly amplified adhans may all yet be found to constitute a noise nuisance in South Africa, if challenged and found to be unreasonable.

Keywords: Muslim call to prayer (adhan or azan); unamplified; amplified; loudspeakers; mosques (masjids); constitution; freedom of religion; cultural heritage; religious symbol; property rights; neighbor law; noise nuisance; noise pollution; South Africa; Indonesia; India

\section{Introduction}

This article approaches the position of the call to prayer (adhan ${ }^{1}$ or azan) in South Africa from the perspective of both legislation and case law. Although only an unamplified adhan, vocalized purely by human voice without the aid of a loudspeaker, has religious status in Islam, Muslim religious authorities (ulama) have since the twentieth century also approved of, and permitted, an amplified adhan.

Currently, Muslims constitute the largest of several religious minorities in a predominantly Christian South Africa. During a period of Dutch and British colonization, Muslims 
were only formally accorded religious freedom some 150 years after their arrival from Indonesia and India in the mid-seventeenth century. Since then the adhan has been rendered in both unamplified and amplified forms from South African mosques (masjids) for some 223 years. However, the unamplified adhan has recently come under the legal and judicial spotlight.

On 21 August 2020 Judge S B Mngadi, in Ellaurie v Madrasah Taleemuddeen Islamic Institute and Another ${ }^{2}$ (hereafter, the Ellaurie case) ruled that the sound of the unamplified adhan emanating from a mosque located on the premises of Madrasah Taleemuddeen (hereafter, the Madrassa ${ }^{3}$ ) should not be audible within the house situated on nearby property belonging to Mr. Ellaurie, a Hindu neighbor. In 2003 and 2004 Mr. Ellaurie had lodged similar complaints about the sound of the adhan emanating from the Madrassa's mosque, respectively, with the EThekwini Municipality (which has jurisdiction in the area on such matters) and the South African Human Rights Commission (hereafter, the SAHRC). His complaints then included a second nearby community mosque, the Isipingo Beach Mosque, which renders adhans through amplification. As a consequence of the outcome of the Ellaurie case, the Madrassa was ordered to reduce the volume of an unamplified adhan, thus impacting on its religious and associated manifestation and the group rights of its students and staff members. As a consequence of wide media coverage, Mr. Ellaurie was also characterized as an "Islamophobe".

On 4 September 2020, the Madrassa (the first respondent) lodged a notice of application for leave to appeal the High Court's decision " ... to the Supreme Court of Appeal [SCA], alternatively the Full Court of the KwaZulu-Natal High Court, against the whole of the judgment and order of Mngadi J"4. On 26 March 2021, the leave to appeal was not granted by Mngadi J and an appeal to the SCA against that ruling is being considered. ${ }^{5}$ In a nutshell, the Madrassa contends that the judgment is flawed as there is a disconnect between the law and the facts of the case. The Judge, in his reasoning and ruling, was criticized by the Madrassa for failing to weigh up and balance the competing human rights interests of the parties pertaining to religious freedom and property (which includes neighbor law), and to apply the common law nuisance principles (which form part of neighbor law) and appropriate case law. The Constitution of the Republic of South Africa, 1996 (hereafter, the final or 1996 Constitution) makes provision for the accommodation of the adhan (and other religious symbols) in a plural South Africa. Although not banned, its manifestation may be restricted if found to be unreasonable. The article examines Mr. Ellaurie's noise nuisance complaint to determine whether it was reasonable and whether or not the legal validity and rationale of the judgment, and therefore its outcome, may be questioned. There is the likelihood that the case may yet proceed all the way to the Constitutional Court (CC) which is the highest (or apex) court in South Africa for constitutional matters, while the SCA, formerly the Appellate Division (AD), is the highest court for criminal and civil cases.

KwaZulu-Natal is one of nine provinces of South Africa where Hindus as a religious minority are concentrated. Although the doctrine of stare decisis ${ }^{6}$, which entails that where facts are similar courts are bound by previous decisions, is part of South African law, the decision in one province is not binding in another. The article highlights that the Ellaurie case may nevertheless yet have far-reaching consequences for the adhan, and for religious symbols generally, because similar complaints have been lodged, albeit against the use of amplified adhans, against several mosques ${ }^{7}$ located in Cape Town, in the Western Cape province, and Tshwane (formerly Pretoria) in the Gauteng province. These are also major cities where Muslims are largely concentrated. Classical Islamic tradition provides little guidance to Muslims as to how to live as minorities. ${ }^{8}$ The article, therefore, also explores the possibility of unamplified adhans being allowed unrestricted rendering in areas where Muslims, as a religious minority, are concentrated, and where historical areas and mosques have been accorded protected status as cultural heritage sites. The article proffers some recommendations for the way forward in South Africa based in some instances on the position of the adhan in several countries and the lessons they may hold. It concludes that, 
ultimately, unamplified, unduly amplified and duly amplified adhans may all yet be found to constitute a noise nuisance in South Africa, if challenged, and found to be unreasonable.

This article is accordingly divided into seven Sections, including this introduction (Section 1) and the conclusions (Section 7) as follows:

Section 2 (i) briefly examines the religious origin and purpose of the early unamplified and later amplified forms of adhan in order to highlight why they are an integral part of the current practice of Islam. Section 2 (ii) examines the historical origin of both forms of adhan in South Africa and its possible status as a protected cultural heritage symbol. It briefly examines past legal discriminations against Muslims in support of the argument (in Section 4) that, in order to avoid past injustices, religious diversity should be celebrated, protected and tolerated.

In South Africa, religious symbols like the adhan may constitute a "noise nuisance" and may be regulated at national, provincial or municipal levels. ${ }^{9}$ The South African Constitution empowers municipalities to both pass and manage their own by-laws. These by-laws have the same legal status as other national and provincial legislation. ${ }^{10}$ Although the EThekwini Municipality (second respondent) did not participate in the case, the properties of Mr. Ellaurie and the Madrassa fall under its jurisdiction. Section 3, therefore, briefly examines the complaint lodged by Mr. Ellaurie with the Municipality; the SAHRC mediation process and its reported recommendations; and the facts and outcome of the Ellaurie case mainly in so far as they pertain to the mosque belonging to the Madrassa. Although Mr. Ellaurie's complaint in the High Court did not include the Isipingo Beach community mosque, brief reference will be made to this mosque and the recommendations pertaining to it insofar as they may shed further light on the case.

Section 4 deals with municipal complaints received about the rendering of the adhan in Cape Town and Gauteng both before and after the Ellaurie case.

Section 5 provides an analysis of competing constitutional rights to religious freedom and property in the context of the Ellaurie case in order to determine whether or not its outcome was justified.

Section 6 proffers some recommendations as to the way forward in South Africa (based in some instances on the position of the adhan in several countries) which may assist courts dealing with matters pertaining to the adhan, and includes co-operation between local ulama (Muslim religious authorities) and the municipalities (as representatives of the State).

\section{The Adhan as a Religious Symbol and as a Cultural Heritage Symbol in South Africa}

This Section highlights that the adhan is a symbol of both religious and cultural significance for Muslims in South Africa.

(i) The adhan as a religious symbol

The adhan is an important practice for the Islamic faith. The origin of the ritual and recitation of the unamplified adhan, by a muezzin (English word derived from the Arabic word "mu'addin") in the Arabic language and in wording that is still in current use, can be traced back to Prophet Muhammad (on whom be peace) and the foundations of Islam in the seventh century. Muhammad wanted to upgrade a then simplified version of the adhan and was inspired by the sounding of the Christian church bell and the Jewish ram's horn (shofar) to introduce the adhan as a dedicated symbol in Islam. ${ }^{11}$ The amplified adhan involving loudspeakers is a more recent innovation. Saudi Arabia ("seat of Islam"), followed by Pakistan ${ }^{12}$ and Singapore ${ }^{13}$, began to use loudspeakers to broadcast the adhan during the 1950s.

The Qur'an (holy book of Islam) revealed to the Prophet Muhammad and his Sunna (received custom or traditions associated with him) are the two primary sources of Islamic legislation. ${ }^{14}$ Muhammad's traditions were collected in book form, known as ahadith (singular, hadith), after his death. ${ }^{15}$ While there are several Qur'anic verses ${ }^{16}$ enjoining believers to pray at "stated times" which may allude to the historical foundation of the 
adhan, the Qur'an does not specifically refer to the adhan. According to the Islamic law (Shari'a) established by the jurists of the four main Sunnite (Hanafite, Malikite, Shafi'ite and Hanbalite) schools of Islamic thought (madhahib, singular: madhhab), the adhan is a Sunna (tradition) established by the Prophet through his personal intervention. Although, therefore, not compulsory, the unamplified adhan is a strongly recommended practice, especially given the fact that Muhammad's Sunna is second in status only to that of the Qur'an. When reference to the adhan is made, as it is in several ahadith, it is taken seriously by Muslims because it embodies his Sunna.

The five obligatory daily prayers constitute one (the second) of the five pillars of Islam. ${ }^{17}$ These five prayers are thus each preceded by the rendering of an adhan primarily to invite Muslims to perform these prayers and to inform them of the arrival of the time for prayer. The Qur'an ${ }^{18}$ dictates the timing of the five prayers to occur in the morning before sunrise (named "fajr" in Arabic); the afternoon (named "thuhr" or "dhuhr" in Arabic); the late afternoon (named "asr" in Arabic); the evening after sunset (named "maghrib" in Arabic); and late at night (named "isha" in Arabic). Factors, such as, location, season and climate, may also play a contributing role. The cycle repeats itself for 365 days of the year and there is no option of occasional occurrences. The adhan for each prayer usually lasts for some three to five minutes.

The wording of the adhan is essentially a summary of Islamic belief. It has been translated into English as follows:

"Allāh [God] is most great. I testify that there is no god but Allāh. I testify that Muhammad is the prophet of Allāh. Come to prayer. Come to salvation [success].

Allāh is most great. There is no god but Allāh." ${ }^{19}$

The adhan begins with an affirmation of the supremacy of God, followed by a profession of faith (consisting of the unity of God, the negation of polytheism, and the confirmation that Muhammad is his Messenger). The actual call to prayer ("come to prayer") only comes after these phrases. Each line is repeated for emphasis.

Singled out for the first (fajr) call to prayer is the additional line: "prayer is better than sleep".

During the COVID-19 lockdown period, muezzins in South Africa were allowed to physically render amplified adhans from mosques. In doing so, they simply replaced the line of the adhan "come to prayer", with the line "pray at home".

(ii) The adhan as a cultural heritage symbol

When 1994 (27 years ago) finally marked the end of apartheid (politically motivated racial segregation) in South Africa, the footprint of Islam had already been firmly rooted in the South African soil for over three and a half centuries. Although a minority group, the history of South African Muslims is inextricably intertwined with South Africa's history of colonialism (the Dutch followed by the British), apartheid, and constitutional democracy. Muslims first arrived as slaves and political exiles on the shores of Cape Town in the mid-17th century, when the Dutch brought them to the Cape from their colonies in the Indonesian Archipelago and India. ${ }^{20}$ A far cry from section 15 of the final South African Constitution, which guarantees Muslims (and other religious minorities) the right to freedom of religion and belief, in 1657 the Dutch introduced a set of laws (the Statutes of India or Code of Batavia (present-day Jakarta) drafted by then Batavian governor Van Diemen in 1642)) which prohibited the public practice of Islam. ${ }^{21}$ As a consequence, Muslims were forced to practice their religion in private and no public congregations were allowed.

Muslims were only formally granted religious freedom by the Dutch authorities in 1804, 150 years after their arrival. ${ }^{22}$ However, its practical implementation was still being hampered during a period of British rule and Muslims still required permission to build mosques. As explained below, the ritual adhan calling Muslims to prayer, preferably in mosques, is a long-standing practice that formally started in Cape Town in 1798, and is a tradition that continues to the present day in other provinces like KwaZulu-Natal (where 
Muslims arrived in the nineteenth century and where the first mosque, the Juma Masjid (also known as the Grey Street Mosque), was built in $1884^{23}$ )) and Gauteng (where the first mosque, the Jumah Mosque (also known as the Kerk Street Mosque) was built in Johannesburg in $\left.1888^{24}\right)$ ) and where Muslims also reside in large numbers.

Muslims constitute a minority in a predominantly Christian South Africa. The current (2020) mid-year population of South Africa is 59.6 million. ${ }^{25}$ Based on the 2015 statistics, Christians were estimated to constitute $86 \%$ of the total population. While Jews were estimated to only constitute $0.2 \%$, Muslims were estimated to constitute $1.9 \%$ (or roughly 1 million) of the total population making them the largest religious minority group at the time. $^{26}$ The majority of South African Muslims are Sunni and mostly followers of the Hanafi and Shafi'i schools of law. The figures indicate that there are currently more Hindus (3.3\%) than Muslims (2.2\%) in KwaZulu-Natal and that the largest number of Muslims are located in the Western Cape (5.3\%), followed by Gauteng (2.4\%) and then KwaZulu-Natal $(2.2 \%){ }^{27}$

There are some 194 mosques in the Western Cape, followed by 78 in KwaZulu-Natal and 19 in Gauteng. ${ }^{28}$

The first, though not the oldest, mosque in Cape Town to install a loudspeaker was the Zeenatul Islam Mosque (also known as the Muir Street Mosque) in 1966. This was followed by other mosques in the area and, lastly, by mosques in the Bo-Kaap. ${ }^{29}$ The Bo-Kaap achieved heritage status in 2019, along with a prayer quarry and six (of eleven) mosques in the are ${ }^{30}$. It is argued that the amplified adhan in these and surrounding areas must also be viewed in its historical context. During apartheid the then government of South Africa had promulgated the Group Areas Act No.41 of 1950 specifically to assign racial groups to different residential areas. While Muslims, in a pre-Group Areas Act and pre-apartheid era, lived in multi-religious and religiously tolerant communities in areas like District Six, for example, today loudspeakers are used in remnants of these communities (some families have recently repatriated back to the District Six area after a restitution process).

In terms of the historical context, the first weekly Friday congregational prayer (jumu'a) was read in a disused stone quarry in Chiappini Street in Cape Town in 1793. ${ }^{31}$ The Qur'an (62:9) highlights that the jumu'a prayer is preceded by an adhan. This implies that the first unamplified adhan was rendered from this site already prior to 1804 when religious freedom was formally granted. The Auwal Mosque ${ }^{32}$ in the Bo-Kaap, the first mosque established in the Cape in 1798 and the oldest mosque in South Africa, was also the first mosque to conduct public prayers. Religious freedom was permitted from 1804 . Hence its establishment "came at a crucial period in the history of the Cape Muslim community"33 and remains symbolic of the recognition of Islam and of the freedom of slaves to worship. Since its establishment, the call to prayer has been rendered for 223 years in South Africa. Thereafter, the proliferation of mosques spread throughout the country.

Since Bo-Kaap and six of its mosques now have protected heritage status, some of its residents are also arguing that the adhan must be part of the city's "living heritage". ${ }^{34}$ I contend that the National Heritage Resources Act No.25 of 1999, given the support for cultural heritage in its provisions, may be a further potential instrument in terms of which the ritual rendering of the adhan can be protected. I briefly explore the possibility of "living heritage" in Section 4, and whether the constitutional right to culture could be invoked in support of such an argument in Section 5.

\section{Mr. Ellaurie's Complaints to the Ethekwini Municipality, the SAHRC and the High Court in Clarifying Context}

It becomes evident from the SAHRC Report ${ }^{35}$, the facts of the case ${ }^{36}$ and Mr. Ellaurie's Founding Affidavit ${ }^{37}$ (in support of his application), that the conflict with the sounding of the adhan, which started when the complaint was first lodged in 2003 with the EThekwini Municipality, was long-standing. After a meeting with the Municipality and interested parties held on 15 December 2003 led to an inconclusive outcome, Mr. Ellaurie reported the matter to the SAHRC on 28 July 2004. As is evident from its report, the SAHRC duly conducted mediation on 1 March $2005^{38}$ and made several recommendations ${ }^{39}$ as far as 
both the Isipingo Beach Mosque and the Madrassa and its mosque were concerned. Mr. Ellaurie decided to remove himself from the process and opted not to sign the report. Given that these were merely recommendations that do not have the same binding and legal effect as a court interdict, Mr. Ellaurie was well within his rights to bring the same complaint to a different forum (the High Court) for further redress and relief. In 2020, some 16 years after the SAHRC mediation process was concluded in 2004, Mr. Ellaurie decided to approach the High Court. The passage of time between the SAHRC and High Court processes is an indication that Mr. Ellaurie's grievances remained unresolved and ongoing.

The complaint to the SAHRC was directed at the adhans emanating from two mosques. First, there is the Isipingo Beach Mosque administered by the Isipingo Beach Muslim Association. This is a larger mosque utilized by the community in the area. As confirmed in the case ${ }^{40}$ it is a separate mosque from that belonging to the Madrassa. According to Mr. Ellaurie it is situated some 200 metres $^{41}$ from his property. Secondly, there is the mosque belonging to the Madrassa itself which is located nearer to Mr. Ellaurie's home. The Madrassa is situated some $20 \mathrm{~m}$ (literally two doors away) from Mr. Ellaurie's property, with another dwelling between the two properties. ${ }^{42}$ While the case simply refers to the Madrassa as an "Islamic institution" or as a "school for Islamic religious studies"43, on its website ${ }^{44}$ the Madrassa Taleemuddeen refers to itself as a "university". As such its vast property consisting of three (numbers 703-705) lots or plots, includes a mosque and "a teaching institution for Islamic religious studies with about 340 students ... and accommodation for staff and students". ${ }^{45}$ The Madrassa's mosque, therefore, serves the needs of its program and of its staff and students, some of whom reside on the property. This would also explain why the Madrassa does not broadcast the adhan through radio or television (as indicated in Para. 15 of the judgment).

This article is primarily concerned with the Madrassa, because Mr. Ellaurie (the applicant) sought an order interdicting only the Madrassa (first respondent) "from emanating calls to Prayer [adhans] that can be heard beyond the boundaries of its property in Isipingo Beach". ${ }^{46}$ The Court granted the interdict and ordered the Madrassa "to ensure that Calls to Prayer made from its property, to wit, Lots 703, 704 and 705 lsipingo Beach, are not audible within the buildings in the applicant's property at ..., lsipingo Beach, Durban" ${ }^{47}$ This confirms that the adhan, whether emanating from the Madrassa or its mosque, must not be audible within Mr. Ellaurie's house (dwelling) only and excludes the areas outside of it. Ironically, it is the Isipingo Beach Mosque that utilizes an "external sound amplifier system" ${ }^{\prime 8}$ whilst the Madrassa's mosque, although it also has such a system, does not utilize it. It is evident in the SAHRC's reported recommendations (which are repeated in the judgment) that the Madrassa's mosque was advised not to use it and from the judgment itself (Para. 15) that it did not intend to do so in the future. The recommendation reads:

"That the siren attached to Madrasah Taleemudeem [which we understand is meant to assist with its operation] to remain [in] its location within the building. That whilst the amplifier system at the [community] mosque being operated by the lsipingo Beach Muslim Association is operational, the Madrasah Teleemudem would not use its facilities to call people to prayer through the sound [a]mplifier outside the mosque." ${ }^{\prime 4}$

It appears that the representative of the Madrassa at the time of the mediation (Moulana M.I Patel) " ... found the recommendation reasonable and supported it". 50

As recorded in the SAHRC reported recommendations, the mediators then were a commissioner from the SAHRC and a commissioner from the Promotion and Protection of the Rights of Cultural, Religious and Linguistic Communities (hereafter, the CRL Rights Commission). ${ }^{51}$

According to the facts of the case ${ }^{52}$, the introduction in his Heads of Argument ${ }^{53}$ and his Founding Affidavit ${ }^{54}$, Mr. Ellaurie currently resides in Isipingo Beach in a property obtained by his family over fifty years ago and that he now owns.

Isipingo, a formerly white area, was declared an Indian area in 1960 in terms of the Group Areas Act. ${ }^{55}$ According to the facts of the case Mr. Ellaurie's family moved to lsipingo Beach in 1966 whilst the Madrassa only acquired its property, some 33 years later, 
in $1999 .{ }^{56}$ Given that there would be churches but not any mosques in that formerly white area, mosques would therefore have to be constructed by the Muslim community to serve their needs. Both mosques were, therefore, only built in the Isipingo Beach area after Mr. Ellaurie's family moved there: the Madrassa's mosque in 1999 or 2000 (now some 21 years old) and the Isipingo Beach Mosque in 1970 (now some 51 years old), four years after his family moved in.

The Madrassa's mosque had only been in operation for some three years at the time Mr. Ellaurie first lodged complaints with the Municipality against both mosques in 2003, while the community Isipingo mosque had already been in operation for some 33 years. Mr. Ellaurie, having lived in the area, therefore had to have been aware of the adhan and its sounding.

Although it is not clear from the SAHRC Report and the Ellaurie case whether or not the Isipingo Beach Mosque may at that stage have been "formally" in compliance with municipal regulations, Mr. Ellaurie chose to target only the Madrassa (even though its adhan was unamplified). However, if Mr. Ellaurie had included the Isipingo Beach Mosque, and its amplified adhan was found not to be compliant with the noise regulations of the applicable by-laws, it would certainly have made for a stronger legal case and more credible precedent.

The current religious leader at the Madrassa, Mufti E. Muhamad, who did not participate in the mediation process, provided the author with further clarity as follows. He confirmed in a personal communication (see Muhamad 2020) that the five daily, but unamplified, adhans are rendered from the mosque on the Madrassa's premises. He explained that the adhan is rendered from an area which, although it still forms part of the mosque, is located one step outside of the building where the shoes of the worshippers or mosque attendees (musallis) are kept. While the adhans are all unamplified, and usually rendered in a moderate tone, this cannot always be controlled. Given the nature of the operations of the Madrassa, where courses ${ }^{57}$ are offered to students of mixed race on both a full-time and part-time basis and include the training to become imams of mosques and ulama (religious leaders), rather than dedicated persons who render the adhan (muezzins), different persons (mostly students), whose voices may differ in volume, render the adhans and this may sometimes result in an increase in their volume. Mr. Ellaurie ${ }^{58}$ subsequently also provided the author with further clarity about his views and the outcome of the case. Mr. Ellaurie's Heads of Argument includes a video clip ${ }^{59}$ of an unamplified adhan rendered from the Madrassa which Mr. Ellaurie had taken from his property after sunset. While the reader is able to view the video and make his or her own assessment, the author, having listened to it, contends that its volume would certainly appear to sound magnified (almost amplified) to someone living in such close proximity to the Madrassa as Mr. Ellaurie did. In the background one can also hear a second adhan being rendered (probably from the Isipingo Beach Mosque) which reinforces the argument (in Section 5 (iii)(d) and Section 6) of clashing of sounds when adhans are not synchronized.

Mr. Ellaurie conducted his own defence ${ }^{60}$ and the presiding Judge made it clear that Mr. Ellaurie was acting on his own behalf and not in the public interest. ${ }^{61} \mathrm{Mr}$. Ellaurie contended that the Madrassa has turned "a [once] diverse, peaceful residential suburb" into "a Muslim enclave". 62

Mr. Ellaurie sought "an order, firstly, interdicting the [Madrassa] from emanating Calls to Prayer that can be heard beyond the boundaries of its property in lsipingo Beach. Secondly, that the [Madrassa] ceases its operations in the area, and its property in the area be sold to the State or to a non-Muslim entity". ${ }^{63}$

The Judge ordered that the Madrassa's volume be toned down and denied the order for the Madrassa to be shut down. ${ }^{64}$ Since Mr. Ellaurie's request for the "banning of the Madrasah from the area" ${ }^{\prime 65}$ was not entertained, the focus of this article is on the first order.

The Municipality (second respondent) was represented in the SAHRC mediation process but did not participate in the Ellaurie case. The eThekwini Municipality "Nuisances and Behavior in Public Places By-law, 2015"66 was published on 11 September 2015 and is 
up to date as at 7 August 2020. Section 8 (1) of the by-law prohibits an unauthorized noise that impairs the convenience or peace of any person as follows:

"No person may in a public place cause or permit to be caused any disturbance or impairment of the convenience or peace of any person by shouting, screaming or making any other loud or persistent noise or sound, including amplified noise or sound, except where such noise or sound is emanating from-(a) an authorised public meeting, gathering, congregation or event" (emphasis added).

The by-law therefore clearly includes within its ambit both unamplified and amplified adhans. In fact, a public law expert points out that "[e]ven a noise that has strictly speaking passed the scientific test required for a noise disturbance might still be considered a noise nuisance if found to be unreasonable" ${ }^{67} \mathrm{Mr}$. Ellaurie provided video evidence to highlight the effect of the noise nuisance on him. However, "[t] he Municipality did not participate in the litigation". 68 The volume of the adhan ("noise nuisance") was, therefore, not established to be in contravention of the municipal noise control regulations.

\section{Municipal Complaints Directed against the Adhan in Cape Town and Gauteng Prior to and Since the Ellaurie Case}

In December 2018, several complaints by a single individual were lodged against the adhan emanating from a mosque (Masjidus Saligeen) located in Strandfontein, a coastal settlement within the jurisdiction of the City of Cape Town Municipality. It is reported in the media that:

"Following meetings with the City and the [Cape-based Muslim Judicial Council] MJC [founded in 1945], it was agreed that the athaan would not be silenced. The entire saga upset Muslims and Christian residents, with thousands signing a petition to apply pressure on the city council." 69

A few months later, in May 2020, and a few months before the outcome of the Ellaurie case in August 2020, the rendering of the adhan at the Zeenatul Islam Mosque in District Six also became a contentious issue after a single complaint was lodged with the City of Cape Town by a person living in a nearby flat. ${ }^{70}$ While the City was obliged, in terms of its municipal noise by-laws, to investigate the complaint, ${ }^{71}$ the City had, as a consequence, apparently gone a step further and "publicly announc[ed] it would amend its noise by-law to exempt religious activity". ${ }^{72}$

According to a statement released by the Office of the Secretary General of the MJC ${ }^{73}$, the MJC had participated in a meeting called by the City of Cape Town on 30 April 2020 after concerns were raised of an alleged intent by the City of Cape Town to amend its existing "Streets, Public Places and the Prevention of Noise Nuisances By-law, 2007"74, notably section 3 dealing with "noise nuisance", which the MJC (and the Muslim community) understood would negatively impact the sounding of the five daily adhans.

Section 3 provides as follows: "No person shall in a public place-(a) cause or permit to be caused a disturbance by shouting, screaming or making any other loud or persistent noise or sound, including amplified noise or sound; or (b) permit noise from a private residence or business to be audible in a public place, except for the purposes of loudspeaker announcements for public meetings or due to the actions of street entertainers" (emphasis added).

The City representatives acknowledged that the by-law was in the process of being updated and apparently assured the MJC that its (singular) proposed change to the by-law was unrelated to places of worship, and therefore, would not have an impact on the adhan. The City did, however, indicate that the rest of the by-law

"will be subjected to further review later [in 2020] or early [in 2021], which will allow for additional amendments, which could also apply to the exemption of places of worship from the current noise nuisance provisions".

The above by-law was opened for public comment in May, 2020. Although many comments were received, no amendments have as yet been approved. ${ }^{75}$ 
The Cape Town by-laws were deemed "insensitive" and are currently under review. In 1966, some 54 years ago, the then apartheid government declared District Six a "whites only" area in terms of the Group Areas Act No.41 of 1950. As a consequence, many Muslim families were among the thousands of residents who were slowly, but forcibly, removed from District Six to other more remote areas over a period of some ten years. ${ }^{76}$ Muslims had no option but to relocate from areas where they had painstakingly raised private funding for, and established, mosques which as endowed ("waqf" in Arabic) property, were fortunately not demolished. They had to start the process from scratch in the areas to which they were subsequently relocated. One such mosque located in District Six is the Zeenatul Islam Mosque in Muir Street established in 1920 by early Muslim settlers from India. This mosque was 100 years old in 2020. Given its age, a cogent case could be made also for it to be declared a heritage site. However, according to a trustee of the mosque, the Muir Street mosque has not applied for such status. ${ }^{77}$ There is an ongoing call for the area to be declared a national heritage site.

A third general complaint is highlighted in a Public Announcement dated 22 August 2020, where the Imam of the Nural Huda mosque in the Bo-Kaap (est. 1958 and declared a heritage site since 2019), alerted the community that on 21 August 2020 (the same day that the judgment in the Ellaurie case was delivered) a complaint had been lodged against the adhan emanating from the mosque and was being investigated. This was the second such complaint directed at this mosque. It is reported that the complainant (like Mr. Ellaurie) had "found the noise disturbing"78. A fourth general complaint (although the third in Bo-Kaap) pertaining to a different mosque in the area (deemed to be the Jamia Masjid (est.1850 and a heritage site since 2019) was also lodged around the same time. Unlike Mr. Ellaurie, the complainants (assuming there was more than one) against the adhan in the Bo-Kaap have not been identified, nor were official notices (summonses) or fines issued. The City of Cape Town law enforcement officers simply paid the respective mosques a formal visit to inform the imams of the complaints against the sounding of the adhan. The three complaints were apparently the first such complaints in the history of the Bo-Kaap and were received in quick succession (within a period of two months).

Falling back on a traditional defence, the Imam indicates that the Nural Huda Mosque in Bo-Kaap was " ... the first mosque [in that area] to have sounded the Athaan over a speaker more than 50 years ago. Those making these complaints expect us to discontinue something we have been doing for many years ..."

It has also been reported that residents believe that "people's lack of knowledge about Bo-Kaap's long history of mosque practices" has led to these complaints being unfairly lodged, and that "[t]hey should know when they buy properties here that the Athaan is part of the package, with all our other customs and practices". ${ }^{80}$ The chairperson of the BoKaap Civic and Ratepayers Association was of the opinion that it needed to be ascertained whether the complaint was due to "intolerance" or "ignorance" since their investigation found that " ... people moving into the area hear the athaan and claim ignorance that they didn't know. People are using this to settle personal scores as we see with the Isipingo case .. ${ }^{\prime 81}$ However, this argument may not exempt mosques from complying with nuisance by-laws as the reverse case scenario can also apply.

It appears that the adhan, even if religious activity is to be exempted from the ambit of the City of Cape Town's municipal noise and nuisance by-laws, will not exempted from being deemed a noise nuisance in terms of the City's by-laws because people already lived there or because people moved into the area subsequently.

If mosques, whether located in residential or business areas, adhere to noise nuisance by-laws, neighbors would not feel compelled to lodge municipal complaints or to move from areas in which they have lived for years (in some cases even before mosques were built). By the same token, while consideration is given to location, businesses or people working there, new or foreign home buyers or businesses should not be deterred from moving into an area simply because of the existence of mosques. However, when persons 
opt to live in such areas, or to establish businesses there, it would be considered reasonable to expect them to tolerate some noise from religious symbols, and regardless of their nature.

The City's executive director for safety and security in another report indicated that although the adhan complaint was "a very technical matter", it did lend itself to "an amicable solution". Further, that "enforcing the city's bylaws was a balancing act between the rights to practi[s]e religion and the rights of residents. "If it is proved that the decibel reading is higher than what is permissible in that area, environmental health staff will contact both parties to find an amicable solution. Sometimes the volume needs to be turned down slightly or the speaker needs to be turned in a different direction. The City's view is that the rights of both parties must be respected" ${ }^{82}$

In approaching the various mosques with complaints, the City of Cape Town was relying on a by-law that is in the process of being amended. Although the complaints against the Bo-Kaap mosques were unprecedented, it can be inferred from the above views expressed by the City's executive director that it is highly unlikely that any proposed amendments to the by-law will exempt the unlawful rendering of an amplified adhan from its ambit. It is contended that the adhan, although of religious origin, is nonetheless only a Sunna (tradition) and even if it is to be considered part of a "living" or "lived" heritage, as is now being called for, it would not be able to enjoy complete legal immunity regardless of whether its sounding is amplified or unamplified. Although Muslims may still appear to be concentrated ${ }^{83}$ in certain parts of the Bo-Kaap, it is not an exclusively Muslim area. The Bo-Kaap is a mixed area where Muslims and Christians live side by side.

It might, however, be cogently argued that it might be an appropriate historical heritage in that the adhan is disseminated by human voice from mosques in areas where Muslims form a majority (as in certain parts of the Bo-Kaap), as it serves the majority. The role of the size of a community (minority or majority) and its impact on the adhan is further explored in the criterion of reasonableness under Section 5 (iii)(b).

On 28 August 2020, barely a week after the outcome of the Ellaurie case, City of Tshwane authorities in the capital city, Pretoria, (in Gauteng Province), following several complaints received from residents, ordered the Raslouw Jamaat Khana, a mosque located in Centurion, Pretoria, to reduce the volume of its broadcasting of the adhan through loudspeakers. ${ }^{84}$

The mosque was served with a notice and ordered by the City of Tshwane's health department to also reduce, with immediate effect, the volume of the sounding of its call to prayer, failing which legal action would be taken. ${ }^{85}$ The notice detailed that the mosque should not "operate, play or allow to be operated or played a radio, television set, drum musical instrument, sound amplifier, loudspeaker system, or a similar device producing, reproducing or amplifying sound so as to cause a noise nuisance". ${ }^{86}$

As is also evident from the notice, it appears that the City of Tshwane has developed a unique, "first of its kind in ... South Africa", Noise Management System ${ }^{87}$ based on its Noise Management Policy ${ }^{88}$. This system (and its procedures-starting with an investigation as a first step and legal action resorted to only as a last measure) provides a good model for other municipalities on how to efficiently handle noise nuisance complaints emanating from religious symbols like the adhan. In three of the four general complaints recounted above, reference is made to media reporting of community responses. In Section 5 (iii)(b) it will be highlighted that, although community opinion is an important determinant in the criterion of reasonableness, such comment may not necessarily be representative of general/predominant community views.

Legal and practical issues of sounding the adhan in a diverse, Muslim-minority context need not be controversial. In some cities of the USA allowances are being made for amplified adhans to be broadcast to the outside. In an example of what in 2004 was construed to be an exception to the national norm for Muslim minorities in the USA, a city council effectively granted a religious exemption from the city's noise ordinances. ${ }^{89}$

In The Netherlands, although amplified adhans have been legally authorised since the 1980s, municipalities are able to restrict unreasonable use of amplification. ${ }^{90}$ Ironically, it 
appears that after initially being banned by Dutch colonisers, support for formal recognition of amplified (and by implication unamplified) adhans in the City of Cape Town can be found in the current and unique Dutch example.

\section{An Analysis of Competing Constitutional Rights to Religious Freedom and Property in the Context of the Ellaurie Case}

The South African Constitution (1996) is the supreme law in South Africa. Since apartheid only ended in 1994, the main aim of the Constitution is to avoid the injustices of the past. The Preamble to the Constitution, although it has little legal value, encourages the South African people to be "united" in their "diversity". Section 15 (1) (freedom of religion, belief and opinion) of the Constitution guarantees the right to freedom of religion to all South Africans and provides as follows: "Everyone has the right to freedom of conscience, religion, thought, belief and opinion." Although section 15 is narrowly constructed and makes no formal reference to manifestation, the apex court has interpreted the right to religious freedom to include the right to manifest and practice such beliefs. However, the fundamental rights protected in its Bill of Rights, including freedom of religion, are not absolute and may be limited in terms of section 36 (1) of the Constitution to promote the public interest or to protect other human rights like property (section 25), for example. Section 36 (1) (limitation clause) contains specific criteria according to which a limitation must be justified. ${ }^{91}$ Although section 36 (1) uses the phrase "reasonable and justifiable" rather than the terms "balancing" or "proportionality" 92 , the Judge, in his reasoning and ruling in the Ellaurie case, was criticized by the Madrassa for failing to weigh up and balance competing rights to religious freedom and property (which includes neighbor law and noise nuisance) and case law pertaining thereto. To test whether this criticism is justified, and whether therefore the Madrassa's appeal may yet meet with success, this section provides an analysis of freedom of religion and property clauses in the Constitution and the common law pertaining to neighbors (noise nuisance) and case law pertaining thereto in the context of the Ellaurie case. Section 39 (2) ${ }^{93}$ (interpretation clause) of the final Constitution encourages us to strive for the achievement of an effective and meaningful development of the common law. This implies an engagement with nuisance law (private law) within the ambit of human rights law (public law). As such, it is divided into three Sub-sections, with some overlap because property law straddles private and public law, as follows: (i) freedom of religion and its manifestation and limitation; (ii) the right to property (neighbor law and noise nuisance); and (iii) the criterion of reasonableness and its four main principles:

(i) Freedom of religion and its manifestation and limitation

The adhan as a religious symbol is an expression of the manifestation of religion. Section 31 (cultural, religious and linguistic communities) deals with the protection of minority rights. Section 15, read together with section 31, guarantees the right of a person belonging to a religious community to enjoy and practice his or her religion with other members of that community. Although the right to religious freedom is always guaranteed and protected, its manifestation may be limited under section 36 if it conflicts with other rights, such as, property (section 25), privacy (section 14), expression (section 16) and environment (section 24), for example, which are also protected. However, even if restricted, some sort of balance has to be sought between the conflicting rights. I contend that since such a balancing of rights did not occur in the Ellaurie case, that therefore, the Madrassa was not treated equally or fairly (section 9). Section 9 (3) provides:

"The state may not unfairly discriminate directly or indirectly against anyone on one or more grounds, including ... religion, conscience, belief, culture [and] language...."

The Judge gave little, if any, consideration to the rights of the students and staff who were exercising their right to religious freedom and the manifestation thereof through the adhan (a ritual and religious symbol) rendered from the mosque on the property of the 
Madrassa and, moreover, failed to conduct a limitation analysis according to the criteria identified in section 36 and interpretive guidelines provided in international law.

I provide the following, often overlapping, further explanation and analysis in support of my contentions.

The Bill of Rights of both the interim ${ }^{94}$ (section 14) and final (section 15) Constitutions contain provisions relating to freedom of religion. However, the interim Constitution did not contain the equivalent of section 31 (1) of the final Constitution. There are Constitutional Court cases in South Africa dealing with both the interim and final Constitutions confirming that "manifestation" is included within the ambit of freedom of religion. In Lawrence 95 , the first case dealing with the right to religious freedom heard by the Constitutional Court (though in the context of section 14 of the interim Constitution which was then still in force), the court (per Chaskalson P) adopted the Supreme Court of Canada's ${ }^{96}$ definition of freedom of religion:

"The essence of the concept of freedom of religion is the right to entertain such religious beliefs as a person chooses, the right to declare religious beliefs openly and without fear of hindrance or reprisal, and the right to manifest religious belief by worship and practice or by teaching and dissemination."

In a separate judgment $\mathrm{O}^{\prime}$ Regan J argued (at Para. 128) that in her view,

"the requirements of the Constitution require ... that the legislature refrain from favouring one religion over others. Fairness and even-handedness in relation to diverse religions is a necessary component of freedom of religion."

While the interpretations of section 14 of the interim Constitution remain relevant to section 15 , based on the values of the final Constitution of equality, freedom and human dignity, and as confirmed in several subsequent court cases referred to in this Sub-section (Pillay, Prince etc.), all religions, beliefs and ideologies are seen as equal in terms of, and protected under, section 15. This implies that the adhan, as a religious symbol, ought not to be subject to different treatment simply because its oral (declamatory) nature may be different from the aural nature of, for example, Christian, Jewish and Hindu religious symbols.

The foundation of a range of individual human rights contained in the Constitution were sourced from international human rights instruments. In 1998 (after the Lawrence case) South Africa ratified the International Covenant on Civil and Political Rights (ICCPR) of 1966. ${ }^{97}$ In terms of section 39 (1)(b) (interpretation clause) and sections 231 to 233 (providing for international law) of the Constitution, courts are obliged to apply the provisions of the ICCPR. The Judge in the Ellaurie case (Para. 11), although relying only on the earlier Lawrence case, correctly interprets the freedom of religion clause of the Constitution to include the manifestation thereof. However, the Judge appears to contradict himself by stating in Para. 16 that while section 15 (1) of the Constitution guarantees everyone the right to religious freedom, " . . it does not guarantee practice or manifestations of religion. The Call to Prayer, is a manifestation of the Islam religion, it is not Islam itself" (emphasis added). Unfortunately, in so doing, the Judge also confuses the integral role of the adhan in Islam and fails to draw a distinction between the status of the unamplified and amplified adhan in Islam.

Although more relevant, but not referred to in the Ellaurie case, the Christian Education ${ }^{98}$ case is a later Constitutional Court case which can be cited in support of section 15 of the final Constitution being interpreted as including the manifestation of religion. Moreover, the Christian case included the right to freedom of religion under sections 15 (1) and 31 (1)(a) of the final Constitution. At Para. 18, Sachs J expresses his approval of the Canadian Supreme Court's definition as quoted by Chaskalson P in the Lawrence case above: "I cannot offer a better definition than this of the main attributes of freedom of religion." The Prince case ${ }^{99}$ is another such later Constitutional Court case which deals with manifestation of religion:

"This Court has on two occasions [Lawrence and Christian cases] considered the contents of the right to freedom of religion ... On each occasion, it has accepted 
that the right to freedom of religion at least comprehends ... (c) the right to manifest such beliefs by worship and practice, teaching and dissemination ... Seen in this context, sections 15 (1) and 31 (1)(a) complement one another ... In the context of religion [section 31 (1)(a)] emphasizes the protection to be given to members of communities united by religion to practi[s]e their religion". Although the Judge in the Ellaurie ${ }^{100}$ case does refer to the Prince case, unfortunately it is in the context of doctrinal entanglement (detailed below) and not manifestation of religion.

Articles 18 (1) and (3) of the ICCPR, respectively, go further than section 15 (which does not formally include manifestation) and include both the manifestation ("to manifest his religion or belief in worship, observance, practice and teaching") and limitation ("limitations as are prescribed by law and are necessary to protect public safety, order, health, or morals or the fundamental rights and freedoms of others") of religious freedom.

The "Siracusa Principles" ${ }^{101}$ is an international guideline published by the UN Commission on Human Rights on how these grounds of limitation should be interpreted in the ICCPR. It makes allowances for States to limit and derogate from certain rights contained in the ICCPR, provides specific conditions on the limitation of rights and contains several general interpretative principles about limitation clauses. For example, it requires States to ensure that a limitation is "prescribed by law", must "pursue a legitimate aim" and is necessary "in a democratic society".

Section 36 (1) of the Constitution (limitation of rights) provides and lists certain criteria as follows:

"The rights in the Bill of Rights may be limited only in terms of law of general application to the extent that the limitation is reasonable and justifiable in an open and democratic society based on human dignity, equality and freedom, taking into account all relevant factors including - (a) the nature of the right; (b) the importance of the purpose of the limitation; (c) the nature and extent of the limitation; (d) the relation between the limitation and its purpose; and (e) less restrictive means to achieve the purpose."

In terms of both the ICCPR and South African constitutional case law, freedom of religion includes the manifestation thereof. The Madrassa (also described in the case as a "school for Islamic religious studies"102) by rendering of the adhan (religious symbol) was giving effect to a manifestation of religious freedom. The adhan is accommodated in a plural South Africa and not banned. Although Judge Mgnadi did not refer to the Pillay case in which the Constitutional Court ${ }^{103}$ stated that if a practice is integral and important for a person or religion it should be respected, he does nonetheless acknowledge the adhan as a manifestation of Islam.

Article 18 (2) of the ICCPR provides that "[n]o one shall be subject to coercion which would impair his freedom to have or to adopt a religion or belief of his choice". Although always protected, religious freedom per se is not absolute and parts of it can be limited. While the forum externum - external manifestation—can be limited under Article 18 (3), the forum internum cannot be limited and is absolute. The manifestation of religious freedom may be limited in terms of the specific criteria detailed in section 36 above. Mr. Ellaurie, in his Founding Affidavit (Para. 81) called upon the court to apply the limitation clause "to stop the Call to Prayer from mosques into the surrounding neighborhood". In doing so, he was seeking to limit the Madrassa's manifestation of its religion and not its religious freedom to do so. In order to answer the question as to whether the adhan (manifestation of faith) can be limited in the instances of the Ellaurie case, the limitation clause (section 36) gives rise to a two-stage enquiry. In Director of Public Prosecutions, Transvaal $^{104}$, the Constitutional Court, in the judgment of Ngcobo J, described this twopronged inquiry as follows:

"The question of whether a right in the Bill of Rights has been violated generally involves a two-pronged enquiry. The first enquiry is whether the invalidated 
provision limits a right in the Bill of Rights. If the provision limits a right in the Bill of Rights, this right must be clearly identified. The second enquiry is whether the limitation is reasonable and justifiable (under section 361 ) of the Constitution ... Courts considering the constitutionality of a statutory provision should therefore adhere to this approach to constitutional adjudication."

Both stages, thus, "themselves encompass a number of enquiries." ${ }^{105}$ It needs to be ascertained whether the limitation was "prescribed by law" and "necessary". The Constitution affords municipal by-laws the same legal status as other national and provincial legislation. Although the Madrassa's adhan was unamplified, the municipal by-law in question included unamplified adhans within its ambit. However, the Madrassa was ordered to tone down the volume of its adhan without it being established that its sounding contravened the by-law. The order may therefore have been unnecessarily drastic especially since the Madrassa gave the assurance that it would not use amplification and since other "less restrictive" measures (to be detailed in Section 6) could have been considered which would also have resulted in a reduction in volume.

A brief engagement with the UN Human Rights Committee's General Comment 22 ${ }^{106}$, highlights that there may yet be scope in the limitation clause of the ICCPR to justify a limitation or reduction of the sound levels of adhans. Renteln ${ }^{107}$ explains that since the exceptions in Article 18 (3) effectively imply a reduction in the scope of the right to religious freedom,

"[t]o provide direction, the Human Rights Committee issued General Comment 22 giving an interpretation of Article 18. It interprets practice as covering a 'broad range of acts'; [including] ... 'the right to build places of worship'. Furthermore $\ldots$ that the restrictions may not be applied in a discriminatory manner. Although there is no reference to religious sounds per se ... With regard to the call to prayer, regulation may be justifiable if it is deemed incompatible with public morals or public health. Some might argue that the frequency of the calls deserves consideration ... evidence regarding the health effects of the call to prayer is non-existent or inconclusive; it is hard to separate the noise levels it produces from general measures of community noise. Yet there are, most assuredly, adverse physical and psychological consequences for those who find the sounds objectionable. Should there be a determination that the decibel level regularly exceeds internationally agreed-upon standards ... then that might provide a basis for limiting the call to prayer... In international law, the limitations clause might provide a rationale for a limitation on sound level. There is some basis for religious exemptions in the international jurisprudence. Whether states would make exception in the case of nuisance or noise pollution for the loud sounds of religious minorities remains to be determined" (emphasis added).

In the first motion of his Founding Affidavit, Mr. Ellaurie calls for the cessation of the Madrassa's broadcasting of the adhan "with or without amplification". Although the basis of his High Court case was the actual volume of the adhan, it appears that his main motivation may have been the silencing (not reducing the volume) of the adhan, whether amplified or not. I, therefore, contend that Mr. Ellaurie, given the implications that the wording of the adhan, as both a summation and declaration of the principal tenets of the Islamic faith, may hold for his Hindu faith, may also have found its wording offensive.

Mr. Ellaurie has indicated in his Founding Affidavit that the 16-year period between the mediation process and his approaching the courts had afforded him the opportunity to study Islam. I quote the following extracts contained in it on Islam and on the adhan in which he states that:

"It ... allow[ed] him the opportunity to study the Muslim religion and what he found was deeply troubling ... In [his] opinion ... there is only one God, the creator of the universe ... [but that he] ... is firmly of the opinion that Muhammad was not a Messenger of God and therefore finds objectionable the following line from the 
Muslim Call to Prayer that is broadcast from mosques: 'I bear witness that the Prophet of the Muslim religion is the Messenger of God'. Allowing a continuation of the Call to Prayer means that our country is giving the nod to racism and bigotry" (emphasis added). ${ }^{108}$

According to the Judge (Para. 17) "[u]nfortunately, the applicant finds the Call to Prayer particularly offensive due to his views towards Islam" (emphasis added).

This is a clear indication that he was offended by some of the wording of the adhan in addition to its sounding. The wording of the first part of the adhan as a manifestation of one (first of several) of the articles of faith in Islam, namely, belief in the existence of one God, would not have been problematic to Mr. Ellaurie because he was also of the opinion that "there is only one God". However, he did have a problem with the second part of the adhan pertaining to the Prophet Muhammad (which forms part of the basic statement of the Islamic faith). It can, therefore, be argued that the implied meaning of the Islamic confession of faith, and therefore the adhan, could be offensive for non-Muslims like Mr. Ellaurie.

In Schirrmacher's opinion ${ }^{109}$, "the muezzin, in making a verbal confession of faith, compels other people to participate in the exercise of another religion five times a day. As a result, this ... touches upon the concept of negative religious freedom". Given the uniqueness of the adhan and the difference between it and other religious symbols, his is a view that I am inclined to agree with. One can therefore argue that the adhan should not only be examined at the level of noise disturbance but also whether it could infringe upon negative religious freedom by the incessant confessional statement imposed on involuntary and coerced listeners like Mr. Ellaurie.

Although I refer below to an Indian High Court case (Moulana Mufti Syed) which deemed that it could, Renteln ${ }^{110}$ effectively rationalizes away a possible argument that the wording of the adhan may be restricted on the basis of section 16 (Freedom of expression) of the South African Constitution:

"One might consider the possibility that the adhan is a question of religious speech. If laws regulate it on the basis of its content, this would clearly constitute an impingement on freedom of speech. However, mandating a lower decibel limit might well be acceptable under time, place, and manner restrictions."

The adhan is rendered and freely expressed in the Arabic language. Given that prayer is an integral part of their faith, most local Muslims may be able to interpret and understand the meaning of the wording of the adhan. However, while many are taught to read and recite their prayers in Arabic, most do not understand Arabic per se. Nonetheless, although Arabic is not one of the eleven official languages of South Africa, it can be inferred that section 30 (language and culture) of the Constitution, read with sections 9 and 31, both permit and protect the use of Arabic as a language, and that section 16 (freedom of expression) guarantees religious speech.

The judgment contains a lengthy Paragraph [4] where the Judge describes what could be construed as Mr. Ellaurie's derogatory view of Islam (including being a religion that promotes "cultural racism"). A few lines of this paragraph, containing the gist thereof, are quoted:

"The applicant is Hindu and ... unashamedly opposed to the Islamic faith, which is propagated by the Madrasah. The applicant regards Islam as a false religion that discriminates against non-Muslims as non-believers ... The applicant holds the view that Islam promotes cultural racism."

The Constitution does not guarantee South Africans the right not to have their religious beliefs or practices questioned or criticized. Regardless of any discomfort it may have caused for the Madrassa, the guarantee contained in section 15 (1) (freedom of religion) afforded Mr. Ellaurie the constitutional right to form, hold and express the opinions he did. However, it appears that he may have gone too far in doing so. In Minister of Home Affairs $v$ Fourie $^{111}$, another important case not referred to in the Ellaurie case, the Constitutional 
Court affirmed that "the rights of ... minority faiths must be fully respected". What is, therefore, problematic, is that the Judge did not ask for the striking out of statements against Islam nor did the judgment include the Madrassa's response countering them. ${ }^{112}$ As a consequence of media reporting of community responses following the outcome of the case, the stigmatizing label "Islamophobe"113 was imposed on Mr. Ellaurie. This was an assertion which he denied and disputed and therefore also challenged with the Press Council. However, Mr. Ellaurie technically lost this case. ${ }^{114}$

Although further along in Paragraph [4] the Judge includes Mr. Ellaurie's averment that Islam as a religion falls outside the protective ambit of the South African Constitution, ${ }^{115}$ the Judge does rectify that it does. The Judge also highlights the SCA case (De Lange) which states that courts may not interfere or question doctrinal practices of religions ("doctrine of entanglement"):

"A court should only become involved in a dispute of this kind where it is strictly necessary for it to do so. Even then it should refrain from determining doctrinal issues in order to avoid entanglement."116

The mixed racial profile of the Madrassa refutes the view that "Islam promotes cultural racism". As far as the adhan is concerned, the very first person tasked with rendering the adhan in Islam was a black man (Bilal ibn Rabah) accorded this role on merit (his resonant and melodious voice). To date, the person who renders the adhan (muezzin) in a mosque in Cape Town, where Islam was also first established, is still referred to as "bilal" in his honor.

The Judge correctly asserts that Courts have a disinclination to get involved with doctrinal matters. The Judge also quotes Ngcobo J, who delivered the minority judgment in the Constitutional Court case of Prince ${ }^{117}$, in support of such disinclination:

"Human beings may freely believe in what they cannot prove. Yet that their beliefs are bizarre, illogical or irrational to others, or are incapable of scientific proof, does not detract from the fact that these are religious beliefs for the purposes of enjoying the protection guaranteed by the right to freedom of religion. The believers should not be put to the proof of their beliefs or faith."

He highlights that courts would need to be guided by expert evidence to deal with matters of doctrinal interpretation and that since there are other mosques in the area, it would be futile to only ban the Madrassa. ${ }^{118}$ The Judge (in Para. 11) provides clear reasoning for his position by saying that Islam is protected by the Constitution. However, the question was not whether Islam is protected under section 15, but whether a very specific manifestation of the faith (the adhan) can be limited in the very specific instances of the Ellaurie case. Para. 11 is the only instance in the case where the Judge refers to the limitation clause: "There is no law of general application envisaged in s 36 of the Constitution, which outlaws Islam." Unfortunately, Judge Mgnadi did not conduct a limitation analysis and therefore it was not ascertained whether the High Court's limitation of the Madrassa's manifestation (through the adhan) of the right to religious freedom was justifiable.

South Africa can heed and take lessons from the Supreme Court (apex court and the court of final appeal) cases dealing with amplified adhans in India (a Muslim minority State) and Indonesia (a Muslim majority State), whence local Muslims originated. In both countries, the human rendering of the adhan is unrestricted.

In India, the unamplified adhan thus far seems to have attracted little challenge because of the acceptance by the courts of the integral role it plays in Islam and the lives of Muslims living there. The use of loudspeakers is permitted in both countries, although its unauthorised use may be restricted by measures in place to restrict its volume. Several High Court and Supreme Court ${ }^{119}$ cases in India dealt with noise pollution justified on the basis of religion. The Indian Supreme Court (in Church of God) has ruled that the adhan rendered by human voice is protected by Article 25 (freedom of religion clause) of the Indian Constitution (1949). However, it can be inferred from some of the cases, that, like South Africa, the rights contained in Article 25 are not absolute and may be subject to 
restrictions (limitations) imposed by other provisions in the Constitution. Since Islam does not prescribe voice amplification, it can also be inferred from the Supreme Court judgment that when voice amplification is used, it must comply with rules regulating noise pollution. The outcome of this decision, is therefore, that all religions in India must comply with this ruling. It is interesting to note that, in comparison, in the USA ${ }^{120}$ and the Netherlands ${ }^{121}$ the use of electronic devices such as megaphones and loudspeakers also fall under constitutional protection.

Meiliana is a recent controversial Indonesian case involving the volume of the adhan as a noise nuisance in the context of freedom of religion which proceeded all the way to the Supreme Court. The objection by Ms Meiliana, a Chinese (Buddhist)-Indonesian woman, to the noise nuisance caused by the loudspeakers was perceived as questioning the "azan" as a religious symbol. As a consequence, she was charged in the District Court with religious blasphemy because of her "hostility" towards Islam. The High Court upheld the District Court's decision and her appeal to the precedent-setting Supreme Court (which upheld the High Court's decision) was rejected. ${ }^{122}$ It appears from the final outcome of the Meiliana case, that the Indonesian courts, in failing to take into consideration the distinction between the status of amplified and unamplified adhans in Islam, may inadvertently be sending out a message that it does not matter whether amplified adhans may be deemed loud by non-Muslims, let alone Muslims (even if they are in the majority). In both India and Indonesia objections to the silencing of amplified adhans often gave rise to communal tension and riots. However, loudspeakers on churches and mosques can mediate religious violence as was the case closer to home in Jos, Nigeria ${ }^{123}$, and in response to which citizens developed "techniques of inattention". Although these examples hold lessons for averting such possible violence locally, ultimately, the sounding of the adhan should not be deterred by agendas of nationalism.

(ii) The right to property (neighbor law and noise nuisance) ${ }^{124}$

This Sub-section will examine the outcome of the Ellaurie case in the context of property law and the nuisance laws that form part of neighbor law. It appears that Judge Mngadi, while elaborating on Mr. Ellaurie's right to both the use and undisturbed enjoyment of his private property $^{125}$, failed to analyze the extent to which South African law guaranteed Mr. Ellaurie such right.

An important function of property law in South Africa is to manage and harmonize competing interests of property owners. As such, it does not bestow on property owners "absolute and unlimited entitlements" and "various limitations exist in the interest of the community and for the benefit of other people" ${ }^{126}$ Pope and Du Plessis ${ }^{127}$ highlight that "overarching criteria of reasonableness and fairness govern neighbor relations in property law ... To determine nuisance in each case, an objective reasonableness test is applied. The enquiry is whether the conduct complained of is to be tolerated."

A valid question is whether the unamplified adhan was found to be unreasonable in terms of such a test and therefore to constitute a noise nuisance warranting an interdict? Pope and Du Plessis ${ }^{128}$ explain that although the personality of the applicant (Mr. Ellaurie) may be relevant, reasonableness applies to the activity complained of (in this case the unamplified adhan), rather than to whether or not the neighbor (in this case the Madrassa) was being reasonable, since it is the former that is the "test for delictual liability". ${ }^{129}$ South African law permits the regulation of objectionable sounds or "noise" if they cause a disturbance. Was the noise, therefore, objectively measured (in decibels) with the use of technical instruments and found to be unacceptable in terms of the by-law of the Ethekwini Municipality? Or was it ascertained to be unacceptable based purely on Mr. Ellaurie's subjective evaluation (and possibly his video evidence)? Was there any attempt to weigh up and strike a balance between the noise (of the Madrassa's adhan) and the peace and quiet (not "silence") (sought by Mr. Ellaurie) to justify lowering its volume?

It appears that the Judge in the Ellaurie case, when he decided that the Madrassa must reduce the volume of the sound of its unamplified adhans, basically not only ignored the Madrassa's right to practice religion, but also ignored neighbor law and relevant case law 
when he conferred on Mr. Ellaurie the right to undisturbed enjoyment of his property, and therefore set a "poor precedent". The Judge failed to follow precedent and as a consequence also set a bad precedent.

The dispute in the Ellaurie case is not an uncommon one in South African neighbor law. There are many examples of neighbor law disputes in reported cases, including precedent setting cases. For example, the Western Cape case, Garden Cities Incorporated Association Not For Gain v Northpine Islamic Society 1999 (2) SA 268 (C), although not binding in KwaZulu-Natal, related directly to the adhan yet was not referred to in the Ellaurie case. In Garden Cities, the applicant, as a result of complaints received from surrounding residents, successfully sought an interdict against the noise nuisance caused by the respondent's loud sounding of an electronically amplified adhan. The applicant, however, had no objection to an unamplified adhan being rendered by a human voice. The applicant had sold a property designated for religious purposes to the respondent to be used to build a mosque. The written agreement contained clauses which specifically prohibited the respondent from utilising sound amplifying equipment (which included a loudspeaker) and that the adhan would be signalled by using a light on top of the minaret of the mosque which would be switched on at the appropriate times of prayer. ${ }^{130}$ Judge Conradie noted in his judgment in Garden Cities that "[a]lthough there was evidence that it had become a widespread practice for calls to prayer to be electronically amplified, there was nothing to suggest that such amplification had become a precept of the Islamic religion after centuries of calls to prayer without sound equipment". ${ }^{131}$ In his comment on the case, Van der Schyff ${ }^{132}$ highlights that although the agreement may have constituted a limitation (in terms of section 36) on the right to religious freedom, it was reasonable because " ... the religious practice was not forbidden but merely a particular form of its expression. The amplification of the call to prayer had thus not been an essential element of Islam".

In the Ellaurie case, the noise nuisance (unamplified adhan) was not found to be unreasonable and therefore the interdict granted in favor of Mr. Ellaurie may not have been justifiable. Furthermore, the Court granted the interdict on the ground of alleged infringement of Mr. Ellaurie's property rights without giving due consideration of how the Madrassa's right to freedom of religion and manifestation thereof (which includes the rendering of the adhan) may limit his property rights. South African neighbor law expects that neighbors (even if they are related as was the case with the Gien brothers detailed below) living in urban areas would endure occasional, reasonable noise nuisances that give rise to disturbances of the peace. For example, when neighbors or their teenagers host occasional parties with loud music and courteously inform each other of the event and possible parking congestion. However, when this becomes a regular activity and neighbors have been approached to no avail it would not be unreasonable to ask law enforcement officers to intervene in terms of the applicable by-law, and to resort to the courts only as a last resort to seek an interdict to stop such events from recurring.

In Gien v Gien $1979(\mathrm{~T})^{133}$, a case that can be described as "nuisance in the narrow sense"134, two brothers were neighbors. The one brother was granted an interdict in terms of which his brother was prohibited from using an apparatus meant to ward off baboons from his property. The loud noise made by the apparatus was a disturbance (nuisance) and found to be unreasonable. The criterion of reasonableness is examined in the next Sub-section with some overlap between the four principles.

(iii) The criterion of reasonableness in neighbor law and the four principles ${ }^{135}$ taken into consideration in its application.

I contend that if the criterion of reasonableness and its principles were applied to the Ellaurie case, the interdict may not necessarily have been denied:

“(a) The nuisance must usually be repetitive or continuous, since a single action of short duration must be tolerated, except if there is a reasonable expectation that the activity will be repeated."

Do the five daily adhans fall within this category? 
The Judge, although he indicates that he did not do so "lightly", granted an interdict in favor of Mr. Ellaurie on the legal basis that he had established that the adhan "interferes with his private space" ${ }^{\prime \prime}{ }^{136}$

"[T]he Call to Prayer by the Madrasah is made five times a day. A person standing outside, in the premises of the Madrasah makes the first call at 03h30 in the morning. [T] he Call to Prayer is a foreign sound, which invades his private space. It bears down over to him. It deprives him of the enjoyment of his property and interrupts his peace and quiet. It further disrupts his sleep, listening to music and meditation."137

Mr. Ellaurie's assertion that the adhan is a "foreign sound" may be discounted by the fact that the Isipingo Beach Mosque was established in the area some four years after his family moved in. He also indicated to me that he found the sound to be "foreign to South Africa". Although Dutch colonization inadvertently imported it into South Africa along with Muslims, it has been rendered here for some 223 years and can therefore hardly be considered to still be foreign. It is also possible that it might refer to its intrusive nature (from the outside into the privacy of the property) rather than solely to the foreignness of the Arabic language.

Mr. Ellaurie's complaint about the timing of the early dawn prayer is not unjustified (especially since it is the only adhan confirming that prayer is better than sleep). The timing of the first (dawn) prayer may be deemed unreasonable. Mr. Ellaurie may reasonably be aggrieved by the fact that the first (of five) daily adhans is recited very early in the morning (prior to sunrise) while he may still be asleep, and the fact that all five (amplified, 200 meters away, and unamplified, 20 meters away) adhans are sounded within close proximity to his home. In fact, Mr. Ellaurie estimated the annual number of adhans as follows: "five times a day, hundred and fifty times a month, and over eighteen hundred times a year". 138 One prayer (the fifth and last) takes places at night after the fourth (sunset) prayer.

Although each adhan only last for a few minutes, the fact of a nuisance and its repetition, rather than its duration, is at issue when determining noise nuisance in South Africa.

In applying the criterion of reasonableness, the AD in the case of Prinsloo $v$ Shaw 1938 $(A)^{139}$ held that "the holding of noisy religious exercises several times per day, which were usually accompanied by the clapping of hands and the stamping of feet, was prohibited by an interdict". 140

In the Prinsloo case ${ }^{141}$, the applicant was the owner of a house in a residential area. The respondent, his neighbor, was a leader of a religious organization who also used his premises to conduct religious services. The distance between their properties was some 21 meters. Services were held on the neighbor's property three times a day, on three days of the week. On the remaining four days of the week there was another service. The Judge in the Ellaurie case unfortunately did not consider the Prinsloo case.

"(b) Only annoying actions which would be unreasonable in the opinion of the community can be seen as an unusual activity."

This Section will highlight that, when it comes to establishing whether noise amounts to nuisance, the role of community "opinion" is an important determinant in the criterion of reasonableness. However, there is no reference to empirical research about community responses to noise nuisance in the Ellaurie case.

Wide media coverage (not included in this article due to space constraints) highlighted that the "community" had expressed support for the adhan being rendered from the Madrassa. Several Muslim religious (ulama) bodies expressed their objections to the Ellaurie judgment and to the lowering (misconstrued as silencing) of the volume of the adhan. These included the Sunni Jamiatul Ulama South Africa (SJUSA) (Durban, South Africa $)^{142}$, the Jamiatul Ulama KwaZulu-Natal (JUKZN) ${ }^{143}$, and the MJC in the Western Cape $^{144}$. However, comment by particular groups and institutions, or on any kind of media, is, or may not, necessarily be representative of general/predominant community views 
and is therefore also not a measure of the correctness or incorrectness of a judgment. De facto representative community views would have to be ascertained by empirical methods. For example, there are a number of Hindu temples, mosques (besides the two mosques referred to in this article) and churches in the Isipingo area. When it comes to public voices, it is therefore also important to consider the phenomenon of a "spiral of silence"145 and a possible "silent majority", which is not detected by only weighing vocal opinions.

The Judge, when referring to his refusal to grant Mr. Ellaurie's requested relief of banning the Madrassa from the area, made a similar observation regarding a lack of empirical evidence. The Judge ${ }^{146}$ pointed out:

"The applicant states ... that ... he was acting on behalf of himself as well as in the public interest. He, however, had no answers when asked which public he was acting on behalf of, or who had given him authority to act. In my view, there is no evidence as to which members of the public share the applicant's sentiments relating to Islam. On an issue where the public is divided, an individual cannot claim to act on behalf of the public."

In doing so the Judge is stating (confirming) that there is diversity of opinion in the community. However, although the Judge alluded to differences of opinion, there appears to be no formal empirical evidence in the case to this effect.

In Section 2 (ii) and Section 4, I argued (in respect to the Bo-Kaap and the unamplified adhan as "living" heritage) that a consideration would be the size of a religious group in a particular community. While this could apply to any religion or culture, more specifically: would this also apply in contexts where Muslims form a minority and others might find it an imposition? If the adhan only serves to call Muslims to prayer, and they are a minority (as they are in KwaZulu-Natal), would not the nuisance to the majority community be of greater weight? Although it can be inferred from information attributed to Mr. Ellaurie that the adhan gave the Isipingo area "a distinctly Muslim atmosphere" and "[ $t$ ]he Muslim community in the area has increased by 30 percent in the past 15 years" ${ }^{\prime 147}$, no empirical evidence is provided in the case to indicate that Muslims may outnumber other religious groups in Isipingo. If Muslims did constitute a majority in the area, it could have made the case for an unamplified (or amplified) adhan to be rendered stronger, but not necessarily that it could continue unhindered and unimpacted by noise nuisance regulations in the relevant by-law.

"(c) The action or activity must be a nuisance according to a normal person."

According to the AD in Prinsloo $v$ Shaw ${ }^{148}$ :

"A resident in a town, and more particularly a resident in a residential neighborhood, is entitled to the ordinary comfort and convenience of his home, and if owing to the actions of his neighbor he is subjected to annoyance or inconvenience greater than that to which a normal person must be expected to submit in contact with his fellow-men, then he has a legal remedy. The standard taken must be the standard not of the perverse or finicking or over-scrupulous person, but of the normal man of sound and liberal tastes and habits."

As detailed in Section 5 (i), Mr. Ellaurie was characterized as an "Islamophobe" and maybe unfairly so.

In many apartheid-designated Indian neighborhoods (after forced removals because of the Group Areas Act) mosques, temples and churches often co-exist harmoniously as centers of religious and cultural activities for their residents. However, this does not mean that complaints cannot be justifiably lodged.

Muslim retired or elderly people living in the vicinity of a mosque usually both await and welcome the call and/or opportunity to perform prayers in congregation at the mosque since it is often a means for social contact with peers outside of the home. However, a small singled out group may not be equated with "the greater good of neighbors". Moreover, if age, disability (example, hearing impairment) and vulnerability are to be introduced 
as criteria, these must be applied in a balanced way, looking at all vulnerable groups, including those who are negatively affected by the adhan, such as people with sleep impairments, hypersensitivity, etc. Mr. Ellaurie's complaint may therefore be warranted. It is indicated in the case that the adhan "interrupts" Mr. Ellaurie's "peace and quiet" and "disrupts his sleep, listening to music and meditation" (Para. 6).

"(d) Aspects like the location of the properties, the zoning of the properties as residential, business or industrial areas, the habits of the inhabitants and the question whether the health of the neighbor might be affected, are important in the determination of the reasonableness of the actions."

Although Mr. Ellaurie may allude otherwise ${ }^{149}$, the properties of the Madrassa (and zoned for such use) relevant to the case "... are in a residential suburb within the jurisdictional area of the second respondent [eThekwini Municipality]". ${ }^{150}$

It was only after the attainment of democracy in South Africa in 1994 that racial segregation and apartheid laws like the Group Areas Act No.41 of 1950 were abolished. It is, therefore, contended that the argument that Mr. Ellaurie's family lived in Isipingo before the Madrassa and its mosque were established there, although a factor, cannot be the deciding factor that should be taken into consideration. The family moved into an area classified as Indian and where it can reasonably be expected that Indians of diverse religions (including Hindu and Muslim) will establish mosques, temples and churches, as indeed was the case. A similar argument holds true for non-Muslims moving into areas in the Western Cape where Muslims may no longer live in sizeable numbers but where mosques already exist and are still in use (for example, the single noise complaint directed against the Muir Street mosque by a current resident) and also against mosques in the Bo-Kaap (a heritage site that has attracted many foreigners ${ }^{151}$ to buy residential properties in the area).

In fact, according to Mngadi, J "[i]t could be argued that [Mr. Ellaurie] moves away from the area ... "152 In Allaclas Investments (Pty) Ltd. E Another v Milnerton Golf Club $\mathcal{E}$ Others [2007] 167 SCA (RSA), the SCA overturned the ruling of the court a quo ${ }^{153}$ and found that golf balls from a neighboring golf course infringed on the home owner's enjoyment of his property. Although the golf course had been in existence since 1925 and the home owner only moved into his house in 2003, a mandatory interdict that the Golf Club must prevent such infringement was granted. ${ }^{154}$ Judge Farlam ${ }^{155}$, citing De Charmoy v Day Star Hatchery (Pty) Ltd. 1967 (4) SA 188 (D) at 192 A-B, made it clear that when home owners live near a golf course, it would not be unreasonable to expect them to endure some form of nuisance caused by "badly hit golf balls". However, citing Assagay Quarries (Pty) Ltd. $v$ Hobbs $1960(4)$ SA $237(\mathrm{~N})$ at 240 G, the Judge highlighted that the nuisance that the appellants had to endure was much more than what they were expected to tolerate in terms of the application of the principle of "give and take, live and let live", which forms the basis of South African law on this point. The Judge was mindful that the golf course had been in existence since 1925 and that, when the property was purchased, the first appellant was aware that it was next to a golf course. While the Judge opined that this would ordinarily have been a relevant factor, "it is clear that the appellants did not know that the hole was badly designed and gave rise to the safety concerns" (emphasis added).

I have pointed out that reasonableness applies to the activity complained of and not whether the neighbor (the Madrassa) was being reasonable. It is stated in the case that the Madrassa gives the further assurance that "[n]o external sound amplification is used in making the Call to Prayer"156 and that it "... has no intention of using external sound amplification [even] in the future". ${ }^{157}$ Although in the Allaclas case (Paras. 8 and 19) a preventative measure (construction of a high net to stop golf balls) appeared to be of little help, this could also have been construed as a proactive step on the Madrassa's part to not further increase the volume of the adhan. Despite the assurances that it did not, and did not intend to, use amplification, the Judge failed to give any real consideration to the fact that the adhan was not an unusual activity for the Madrassa and the right to manifest religious belief of those worshipping, teaching and learning at the Madrassa. ${ }^{158}$ I contend that had 
the management of the Madrassa applied to the Municipality to use its voice amplification system and if it did so within the parameters of the law, this would have resulted in greater disturbance to Mr. Ellaurie. The fact that there is already a community mosque in the vicinity of the Madrassa that uses a voice amplification system is probably why the Madrassa, in consideration of its neighbors, would have considered it to be duplicitous for it to also render the adhan over its own voice amplification system. Given the timing of the adhans, it would have resulted in a cacophony of colliding sounds which would have caused a further noise nuisance for the residents of the area, including Mr. Ellaurie. This may also be why Mr. Ellaurie decided to be proactive and call for the cessation of the Madrassa's broadcasting of both forms of adhans in his Founding Affidavit. ${ }^{159}$

While the Allaclas case reminds us that each case is decided on its own merits (in this case its unique deciding factor was a "badly designed hole"), it is also evident from the Durban and Natal cases cited by Judge Farlam that the Judge in the Ellaurie case failed to apply the precedents of his own province.

Thus, if there are mosques from which amplified adhans are rendered in contravention of municipal by-laws, then irate neighbors are not necessarily obliged to tolerate them in terms of the principle of "give and take" or "live and let live". In fact, even if the adhans do comply, they can still be found to be unreasonable and such conduct could still be interdicted. In the Ellaurie case it should also not have mattered, or been of much relevance, that Mr. Ellaurie moved into the Isipingo Beach area before the Madrassa was established. By the same logic, the SCA ruling also implies that even if non-Muslim residents in Bo-Kaap in Cape Town moved in after the establishment of mosques in the area, the volume of the adhans rendered from their precincts must not be in excess of the by-laws. This does not detract from the fact that the adhan is a religious symbol and its sounding an integral part of the rich cultural and historical make-up of the area. The decision in the Ellaurie case should be overturned because it had little, if any, sound basis in either public or private law and case law. If not, it may yet have dire ramifications not only for the adhan but for the symbols of other religions and cultures since sounds emitted from all religious symbols can be defined as "noise".

\section{Some Recommendations for the Way Forward}

The adhan is an integral part of Islam and the culture of South African Muslims. In addition to the physical rendering of adhans from mosques, and not in lieu thereof, pre-recorded adhans are also broadcast in homes using radio and television transmissions. Recently, more people are utilizing digital technology like dedicated adhan apps on cellular (mobile) phones. Although it is broadcast over dedicated Muslim radio stations five times a day, this does not preclude (nor do I foresee it replacing it anytime soon) its daily rendition from mosques (with and without amplification) five times a day. Nor did it preclude it during the COVID-19 lockdown periods when government, with the support of most Muslim religious scholars (ulama), ordered the formal closure of mosques. For this reason, the local suggestion (in the Garden Cities case) of "using a light on top of a minaret" in lieu of the adhan to signal the call to prayer, will not work in South Africa. I propose that for the sake of good neighborliness that the ulama continue along this forward-thinking trajectory as far as the adhan is concerned.

While there are other judgments that do (Garden Cities), it is unfortunate that the Ellaurie judgment does not, set a credible precedent on the law relating to the adhan in South Africa. To make the job of municipalities (and ultimately, the courts) easier, and in keeping with some of the recommendations made by the SAHRC in respect of the Isipingo Beach Mosque (as detailed in Para. $8^{160}$ of the Ellaurie case), I recommend that the two major national ulama (religious) umbrella bodies in South Africa, the Jamiatul Ulama of South Africa (JUSA) established in 1970, and the United Ulama Council of South Africa (UUCSA) established in $1994^{161}$, although they usually compete with each other, collaborate to issue formal legal opinions or directives known as fatawas (singular, fatwa) (as was suggested in Indonesia ${ }^{162}$ ) in order to provide the imams and managements of 
mosques located in the different provinces with uniform guidance as to the regulation of both the sound volume and timing of adhans. The provinces referred to in this article each have their own Muslim theological bodies and imams of mosques are members of these organizations. These local bodies are also members of the national bodies. This will ensure a, more or less, uniform rendering of amplified and unamplified adhans along the following lines:

A dedicated muezzin should ideally be appointed and should preferably be schooled in both the art of rendering the adhan and the proper use of modern technology (microphones and sound amplification); an adhan should be timed to not last longer than three to five minutes; if there is more than one mosque in a neighborhood, the timing of the adhans should be synchronized to avoid further noise nuisance; since according to the Hanafite school of law (which the Madrassa follows), the timing (waqt) of the late afternoon prayer (asr) commences much later than is the case for all the other schools, a comprise should be reached so that the adhan for this prayer is only rendered once; to avoid potential clashes with the provisions of municipal by-laws (which generally do not allow for noise nuisances early in the morning or late at night), the adhan for the first (dawn) and last (late night) of the five daily prayers should be unamplified (loudspeaker muted) and recited only by human voice preferably within the precincts of the mosque rather than atop a minaret; not only does the timing of adhans vary according to the season, but the sounding of the first adhan at dawn occurs when most people may still be asleep and the final adhan occurs at night when some people may have just retired to bed. Some Muslims, young and old, who may not be able to perform prayers, or who may not be as devoted to performing their prayers on time, may also welcome this consideration. Since it would be difficult to distinguish between noise levels resulting from the adhan from general community noises in the area, the remaining three adhans should be allowed to be rendered through amplification; given that, for practical reasons, mosques may not be able to afford the appointment of dedicated muezzins, and that therefore the random persons (imam, muezzin, caretaker, or failing them, a worshipper present in the mosque) rendering the adhan may differ on a daily basis, to obviate both the discretion and disparity of the reciter, the sounding of the amplified adhans for the remaining three compulsory prayers, and those rendered for weekly, and occasional celebratory, congregational prayers, should be fixed at a moderate tone (as is the case in Pakistan ${ }^{163}$ ) and an appropriate decibel level in conformity with municipal by-laws and through collaboration and consultation between ulama and municipalities (as representatives of the State). Along the lines of their counterparts in Singapore ${ }^{164}$, consideration should be given to issuing a national fatwa to the effect that the loudspeakers of new or proposed mosques be directed towards the interior in order to minimize noise. Given that the duration of these adhans may be short-lived, they should be tolerated as long as they comply with the noise parameters of by-laws; the sounding of unamplified adhans are also subject to by-laws and should therefore strive to be reasonable. Mosques that do not comply with the fatawas should be disciplined.

Although the Madrassa may contend that the adhan is technically rendered from inside the building, according to Mr. Ellaurie ${ }^{165}$ (and his video recording appears to support this) the unamplified adhan from the Madrassa's mosque was rendered from outside of the mosque, though not from a minaret. Since the nearby Isipingo Mosque uses amplification, I proffer the following suggestions for the Madrassa's mosque, and my rationale therefor, as a reasonable compromise. The Madrassa could reduce the volume of its unamplified adhan to a moderate level and strive to regulate its volume (which it admits can vary due to a range of factors) in accordance with some of the recommendations proffered in this Section. It could also consider rendering the first (dawn) and last (night) 
adhans from inside its mosque. Given other peripheral and surrounding noises in the area during the day which residents are in any case subjected to, the remaining adhans could still be rendered from outside. Since the Madrassa's adhan is meant primarily for its staff and students (some of whom live on the premises), doing so will not only pose less of a noise nuisance to especially its non-Muslim neighbors like Mr. Ellaurie, but will engender harmonious relationships and go a long way in fostering social cohesion.

Such compromise and accommodation would find condonation in the two primary sources of Islam, namely, the Qur'an and Sunna. Muslims regard the Prophet Muhammad as a role model and aspire to emulate his character and behavior. South African Muslims should therefore be mindful of the numerous rights he bestowed upon neighbors, and his tolerant behavior even towards a disrespectful neighbor, who both vilified his character and physically harmed him. The seventh century Qur'an is likened to a religious Constitution by Muslims. The following Qur'anic verse can be interpreted to advocate mutual rights and duties of neighbors regardless of their nearness to, or physical distance from, each other: " $\ldots$ do good- to ... neighbors who are near [and] neighbors who are strangers [far]". ${ }^{166}$ It is also evident from several, including authentic, traditions (ahadith) ${ }^{167}$ attributed to the Prophet of Islam, that good and kind treatment of neighbors is part and parcel of the conduct of being Muslim (faith).

The South African Constitution (supreme law) both safeguards and limits the diverse religious, cultural and customary rights, practices and identities of its citizens. The role that mosques can play in educating neighbors about the purpose of the adhan in the religious practice of Muslims is an important element in contributing to good neighborliness and avoiding unnecessary lawsuits and complaints based on possible or perceived Islamophobia. A successful practical example of fostering a climate of religious tolerance and interfaith dialogue is the participation of some 45 mosques from six provinces in South Africa in the 2019 "National Mosque Open Day" hosted by the South African Muslim Network (SAMNET), an NGO located in Durban, and in which over 2000 people of various faiths participated. ${ }^{168}$

In order to avoid unnecessary complaints, lawsuits and friction among neighbors, I recommend the following as a further way forward. The City of Cape Town municipal by-laws are in the process of being amended and this may be a good opportunity to emulate and model some of the unique provisions of the Noise Management System of the City of Tshwane referred to in Section 4. Municipalities should also not wait for mosques to comply with their by-laws. Instead, they should be proactive and undertake regular site visits and inspections to assist mosques, that do not have the requisite permission to render amplified adhans, with their applications, and to ensure that, as part of responsible mosque administration, those who have such permission do not abuse this privilege.

\section{Conclusions}

This article has approached the position of the adhan in South Africa from the perspective of both legislation and case law.

Although both forms are permitted, the traditional rendering of the adhan through human voice, though not its later amplification, is an integral part of Islam. This religious position has been reaffirmed in the Indian cases and in the Garden Cities case. Nonetheless, although the adhan is a Sunna (tradition) introduced by the Prophet Muhammad some 1400 years ago and therefore not compulsory, it has been practiced since then without becoming outdated. The adhan is primarily used for spiritual purposes, its main purpose being to remind Muslims to heed the call to prayer, not to force them to do so. A Muslim's faith is not measured by the loudness of the adhan and mosques that do not use loudspeakers or microphones still perform their religious function.

As far as the amplified adhan is concerned, Renteln ${ }^{169}$ astutely observes:

"As people migrated to live in pluralistic societies, the sound of the adhan has sometimes been startling to others. Because of its frequency and volume, there has been, in some quarters, little tolerance for it." 
Although, as detailed in Section 2 (ii) and Section 4, we are now having to contend with similar situations in the District Six and Bo-Kaap areas, the dynamics of forced removals during apartheid makes the comparison different in South Africa. Past discriminations against Muslims in South Africa support the argument that religious diversity should be celebrated and protected to avoid the injustices of the past. This, after all, is the main aim of the Constitution. The size of a community should be of little or no consequence when it comes to the rendering of amplified adhans that have not sought approval, or those that did but still do not comply with by-laws. However, I contend that it should make a difference whether a religious group is a minority or the majority when it comes to permitting the rendering of an unamplified adhan. If it is the majority, it should be allowed. However, this form of rendering may also be subject to restriction if found to be unreasonable.

In South Africa all religions are accorded equitable treatment under the final Constitution. The practices of all religions may therefore be considered to constitute a noise nuisance. By-laws aim to regulate the volume of all religious sounds and all religious symbols are subject to its provisions. The general implications of the Ellaurie case for religious tolerance and use of religious symbols may therefore be far-reaching. Singling out the adhan for attenuation (lessening volume) would be unlawful and amount to discrimination on the basis of religion. If, rather than loudspeakers or other forms of amplification, recourse should instead be had to readily available forms of "digital technologies", as suggested by some critics of an amplified adhan, then this implies that all religions, including Mr. Ellaurie's Hinduism, will have to resort to these modes.

Noise pollution in relation to religion is a sensitive issue and ultimately one that mediation (which proved inconclusive between Mr. Ellaurie and the Madrassa), by-laws or the Constitution may not resolve amicably.

Section 5 highlights some instances in the Ellaurie case where opposite conclusions can be derived from the discussion of reasonableness and that Mr. Ellaurie's noise nuisance complaint may not necessarily have been unreasonable. Nonetheless, I conclude that the Madrassa's appeal, if it continues, should meet with success. Judge Mngadi ignored precedent, set a poor precedent by ignoring property law, and misapplied constitutional law. Given, too, his failure to apply the law to the facts, questions of a fair trial (though not a mistrial) and bias also arise. Procedurally a mistrial cannot be declared after the trial has been finalized; at best, the appeals procedure is available. All of these lead me to believe that the Ellaurie case will be overturned on appeal. I further conclude that the Ellaurie case may not withstand constitutional challenge should the Madrassa opt for that further route if its current appeal fails.

Notions of transformative constitutionalism and the spirit of "ubuntu" (an African concept that has been translated as "the essence of being human"170) characterize South Africa's constitutional democracy. If need be, it is hoped that the Ellaurie case proceeds all the way to the Constitutional Court so that a guiding national precedent can be set to deal with complaints against contestable adhans whether rendered through human voice or over loudspeakers.

Even if, as proposed for the City of Cape Town, by-laws were to exempt religious activity from its ambit, ultimately, unamplified, unduly amplified (unauthorized) and duly amplified (authorized) adhans may all yet be found to constitute a noise nuisance in South Africa and restricted, if challenged and found to be unreasonable. Support for this is found in the similar provisions of by-laws and the limitation clause of the Constitution. If compliant with municipal guidelines, both forms of the adhan should be tolerated and not unduly challenged.

As Justice Sachs stated in the Fourie case pertaining to same-sex relations but which, as a precedent setting case, remains relevant:

"[W]hat is at stake is not simply a question of removing an injustice experienced by a particular section of the community. At issue is a need to affirm the very character of our society as one based on tolerance and mutual respect. The test of tolerance is not how one finds space for people with whom, and practices with 
which, one feels comfortable, but how one accommodates the expression of what is discomfiting." 171

Funding: This research received no external funding.

Institutional Review Board Statement: Not applicable.

Informed Consent Statement: Not applicable.

Data Availability Statement: Not applicable.

Conflicts of Interest: The author declares no conflict of interest.

\section{Notes}

1 The meaning of the Arabic word "adhan" (literally "announcement") emphasises its audible nature. For purposes of this article the Arabic spelling "adhan" is used unless otherwise referred to in references.

2 [Case Number] (3848/2019) [2020] ZAKZDHC [The High Court of South Africa Kwazulu-Natal Local Division, Durban] 32 (21 August 2020).

3 This article uses the Merriam-Webster Dictionary spelling "madrassa" when referring to the "Madrasah Taleemuddeen" for the sake of convenience, unless otherwise indicated in references. The Dictionary also defines a madrassa as "a Muslim school, college, or university that is often part of a mosque". See (Merriam-Webster 2021, Definition of madrassa).

4 As extracted from the cover page of the copy of this notice in the possession of the author.

5 (Lutchman 2021).

6 (De Vos and Freedman 2021, p. 928).

7 The names of the mosques in Cape Town were: Masjidus Saligeen; Zeenatul Islam (Muir Street) Mosque, Nural Huda Masjid and Jamia Masjid. In Tshwane the name of the mosque was the Raslouw Jamaat Khana.

8 (Moosa 1996, p. 162).

9 The Noise Control Regulations (G.N. R. 154 of 1992) in terms of Section 25 of the Environment Conservation Act 73 of 1989 (updated to 18 September 2009) allow provinces and municipalities to formulate their own noise control by-laws.

10 See Open By-laws South Africa.

11 For details see (Sahih al-Bukhari, vol. 1, p. 355 (Book 10: The book of Adhan. chp. 1, Hadith 603-604) and chp. 2, Hadith 605-606)).

12 (Khan 2011, pp. 571-94, see especially pp. 572-74, 592).

13 See (Lee 1999, p. 97, n 7).

14 (Moosa 2011, pp. 8-10).

15 (Moosa 2011, p. 26).

See Q.9:3; Q.4:103; Q.5:58 and Q.62:9. The Qur'anic references are given between parenthesis. The first number is the number of the chapter. The number following the separating colon indicates the verse. 
See (Davids 1980, p 93).

See (VOC News 2020).

South African Human Rights Commission (SAHRC) Mediation Report 2005. The, author would like to thank Mr. Aslam Mayat, the instructing attorney for the Madrassa in the High Court case, for supplying her with a copy of the report and for clarifying its content through personal communication on several occasions in December 2020. (See Mayat 2020).

Para. 8.

Founding Affidavit of CG Ellaurie, 14 May 2019, pp. 4-47 at p. 10. The author would like to thank Mr. Mayat for supplying her with a copy. The pages are numbered and contains paragraphs.

This date is provided in the Founding Affidavit of CG Ellaurie, 14 May 2019, p. 10 at Para. 18.

See text to footnote 49 for the recommendation pertaining to the Madrassa. For a summary of the remaining recommendations see footnote 160 .

See Para. 14.

South African Human Rights Commission (SAHRC) Mediation Report 2005, pp. 2-3.

Para. 3.

Para. 14.

See (Al-Haadi Website of Madrasah Taleemuddeen 2020b).

Para. 3.

Para. 1.

Para. 21 (1). Emphasis added.

Para. 8 (1).

Para. 8, point 6 . The grammatical errors in this quotation are quoted verbatim. For a summary of the remaining recommendations see footnote 160 .

Para. 8.

Para. 8. The SAHRC and the CRL Rights Commission are both organisations established in terms of Chapter 9 of the 1996 Constitution to safeguard democracy.

Para. 3.

See Applicant's Heads of Argument, 29 July 2020, p. 3. The author would like to thank Mr. Ellaurie for supplying her with a copy.

Founding Affidavit of CG Ellaurie, 14 May 2019, p. 5 at Paras. 1-2.

For details see (South Durban Basin 2020, pp. 1-18).

Para. 5.

For details see (Al-Haadi Website of Madrasah Taleemuddeen 2020a. Madrasah Courses).

(Ellaurie 2021).

See Applicant's Evidence of Call to Prayer at the Madrasah property: http:/ /mlnr.org/C2P/DurbanHighCourt. Case3848of2019.C2PVideo.mp4, accessed on 7 March 2021, available in Applicant's Heads of Argument, 2020, pp. 5, 13.

Para. 2.

Para. 10

Para. 5.

Para. 1. Emphasis added.

Para. 21 (2).

Ellaurie case, Para. 10.

See eThekwini, South Africa: Nuisances and Behaviour in Public Places By-law 2015.

(Van Coller 2020). Emphasis added.

Para. 2.

See (VOC News 2020).

For details see (Mandela 2019). See also (Mohamed 2020a) and (Scharnick-Udemans 2019).

(Bantom 2020).

See (VOC News 2020).

See (Muslim Judicial Council (SA)).

Published on 28 September 2007, this is the latest version of this by-law.

See (VOC News 2020).

See (Charles 2020). 
(Mohamed 2020b).

See (VOC News 2020).

(Bantom 2020).

(Ishmail 2020).

See (VOC News 2020).

See (VOC News 2020).

According to information in the 2011 census, the majority (56.9\%) of the inhabitants in the Bo-Kaap still recorded Islam as their religion as opposed to the $4,9 \%$ who identified with Christianity. For details see (Kotze 2013, pp. 128-29).

For details see (Mitchley 2020).

(Lutchman and Somduth 2020).

(Lutchman and Somduth 2020).

For details see (City of Tshwane Noise Pollution).

For details see (City of Tshwane Noise Management Policy).

For a detailed account see ((Weiner 2014, Introduction (pp. 1, 13-14) and chp. 6, pp. 158-94)).

(Arab 2017, pp. 9, 12, 67-69).

(De Vos and Freedman 2021, pp. 430-31).

For a detailed explanation see see (De Vos and Freedman 2021, p. 436).

When interpreting any legislation, and when developing the common law or customary law, every court, tribunal or forum must promote the spirit, purport and objects of the Bill of Rights.

Constitution of the Republic of South Africa, Act 200 of 1993.

S v Lawrence; S v Negal; S v Solberg (CCT38/96, CCT39/96, CCT40/96) [1997] (10) BCLR 1348 (CC) at Para. 92.

$R v$ Big M Drug Mart Ltd (1985) 13 CRR 64 at 97.

See (Amien et al. 2018, p. 75, note 87).

Christian Education South Africa v Minister of Education (CCT4/00) [2000] ZACC 11; 2000 (4) SA 757; 2000 (10) BCLR 1051 (18 August 2000) at Paras. 18-19.

Prince v President of the Law Society of the Cape of Good Hope (CCT36/00) [2002] ZACC 1; 2002 (2) SA 794; 2002 (3) BCLR 231 (25 January 2002) at Paras. 38-39.

See Paras. 110 and 112.

UN Commission on Human Rights, The Siracusa Principles, 28 September 1984.

Para. 14.

See MEC for Education: Kwazulu-Natal and Others v Pillay (CCT 51/06) [2007] ZACC 21; 2008 (1) SA 474 (CC); 2008 (2) BCLR 99 (CC) (5 October 2007) .

Director of Public Prosecutions, Transvaal v Minister for Justice and Constitutional Development and Others (CCT 36/08) [2009] ZACC 8; 2009 (4) SA 222 (CC); 2009 (2) SACR 130 (CC); 2009 (7) BCLR 637 (CC) (1 April 2009) at Para. 141.

(De Vos and Freedman 2021, p. 432). A discussion of each stage falls beyond the scope of this article. For further detail see (De Vos and Freedman 2021, pp. 438-75).

UN Human Rights Committee, CCPR General Comment No. 22, 30 July 1993.

(Renteln 2014, pp. 399-400).

Founding Affidavit of CG Ellaurie, 14 May 2019, p. 12-13 at Para. 36 and pp. 20-21 at Paras. 68 and 74-75.

Schirrmacher $(2015$, p. 8).

(Renteln 2014, p. 401).

See Minister of Home Affairs and Another v Fourie and Another (CCT 60/04) [2005] ZACC 19; 2006 (3) BCLR 355 (CC); 2006 (1) SA 524 (CC) (1 December 2005) at Para. 89.

"The Madrasah, in its answering affidavit, states that the applicant's averments are liable to be struck out as vexatious and irrelevant ... the Madrasah's averments in the answering affidavit in answer to the applicant's vexatious and irrelevant averments have not been included in this judgment" (Para. 9). See also Para. 11.

Using the Oxford Lexico definition, the Press Ombudsman defined "Islamophobia"as: "Dislike of or prejudice against Islam or Muslims ... " For details see (Press Council South Africa 2020).

For details see (Press Council South Africa 2020).

Para. 4.

De Lange v Presiding Bishop, Methodist Church of Southern Africa \& another 2015 (1) SA 106 (SCA) at Para. 39. See Para. 12 of the Ellauriecase. 
Prince v President of the Law Society of the Cape of Good Hope (CCT36/00) [2002] ZACC 1; 2002 (2) SA 794; 2002 (3) BCLR 231 (25 January 2002) at Para. 42. See Para. 13 of the Ellaurie case.

Paras. 12 and 13.

Moulana Mufti Syed Md. Noorur Rehman Barkati \& Ors. ... vs. State of West Bengal and Ors AIR 1999 Cal 15 at Paras. 7, 8 and 27; Church of God (Full Gospel) in India v. K.K.R. Majestic Colony Welfare Association AIR 2000 SC 2773. The precedent setting Church of God case was recently upheld in Afzal Ansari and 2 Others vs State of U.P. And 2 Others. PUBLIC INTEREST LITIGATION (PIL) No. 570 of 2020 at Paras. 25, 38, 39 and 40.

(Weiner 2014, pp. 12-13). In books on the subject which discuss legal and practical issues of sounding the adhan in a diverse, Muslim-minority context.

(Arab 2017, pp. 78, 107).

Putusan PN MEDAN Nomor [Decision Number] 1612/Pid.B/2018/ PN Mdn. Tanggal [date] 4 June 2018-Meiliana (TERDAKWA) [Accused] (District Court); Putusan PT MEDAN Nomor [Decision Number] 784/ PID/ 2018/ PT MDN. Tanggal [date] 25 October 2018 (High Court) and Decision Number 322 K/PID/2019 (Supreme Court). The author would like to thank Professor Euis Nurlaelawati (UIN, Yogyakarta, Indonesia) for her assistance with securing the case numbers. See (Nurlaelawati 2020).

(Larkin 2014, pp. 989-1015).

The information pertaining to neighbour law, including relevant case law, used in this Sub-section has primarily been summarised from (Van der Walt and Pienaar 2016, pp. 99-103, 109-10). Reference is also made to (Pope and Du Plessis 2020, pp. 141-46).

Paras. 17 and 19.

(Van der Walt and Pienaar 2016, p. 109).

(Pope and Du Plessis 2020, pp. 142-43). Emphasis added.

(Pope and Du Plessis 2020, pp. 143-44).

(Pope and Du Plessis 2020).

Garden Cities Incorporated Association Not For Gain v Northpine Islamic Society 1999 (2) SA 268 (C) at p. 268.

Garden Cities Incorporated Association Not For Gain v Northpine Islamic Society 1999 (2) SA 268 (C) at p. 269.

(Van der Schyff 2002, pp. 379-80).

Gien $v$ Gien 19792 SA 1113 (T) at pp. 1114-15.

(Van der Walt and Pienaar 2016, p. 100).

These are summarised from (Van der Walt and Pienaar 2016, p. 101).

Para. 20.

Para. 6. Emphasis added.

Applicant's Heads of Argument 2020, p. 6.

Prinsloo v Shaw 1938 AD 570.

(Van der Walt and Pienaar 2016, p. 101).

Prinsloo v Shaw 1938 AD 570 at 573.

See (Sunni Jamiatul Ulama South Africa (SJUSA)).

See (Jamiatul Ulama KwaZulu-Natal 2020).

See (Pillay 2020 and Swart 2020).

The spiral of silence theory was proposed by the German political scientist Noelle-Neumann in 1974. For details see (Petersen 2019).

Para. 10. Emphasis added.

Para. 7.

Prinsloo $v$ Shaw 1938 AD 570 at 575. Emphasis added.

Para. 5 of the case.

Para. 3 of the case.

According to information provided in 2016 by the chairman of the Bo-Kaap Civic Association, Mr. Osman Shaboodien, about 15 percent of the 1100 [roughly 165] residences in the Bo-Kaap were owned by "outsiders". For details see (Onishi 2016).

Para. 20.

Allaclas Investments (Pty) Ltd v Milnerton Golf Club (Stelzner and others Intervening) 2007 (2) SA 40 (C).

Paras. 4 and 5.

At Para. 21.

Para. 14 
Para. 15.

See Paras. 17 and 19.

(Founding Affidavit 2019, p. 6).

Six recommendations are listed in Para. 8 and are summarised as follows. (1) The Isipingo Beach Mosque should not utilise a loudspeaker during the first (early morning) adhan; (2) an appropriate level of amplification for the remaining four adhans should be determined in consultation with the Municipality; (3) Once there is agreement as to this level of amplification, it should not be indiscriminately varied by the persons rendering the adhan; (4) Each adhan should not exceed three minutes in duration; (5) the persons rendering the adhan is trained to use the sound equipment. The details of point six has been elaborated in the text to footnote 49. It basically entails that while the Isipingo Beach Mosque is using a loudspeaker to render adhans, that the Madrassa's mosque desists from using its loudspeaker.

For detail, see (Moosa 2011, p. 152).

Recognising a "loudspeaker war between mosques in the same area vying to outdo each other", Indonesia set up a team to officially address the ensuing environmental issue. Acknowledging that this may be a difficult issue to address, it was suggested that the Indonesian Council of Ulema issue a fatwa (a formal legal opinion) on the matter. For details see (The Guardian 2015). As a direct consequence of the outcry and violence that ensued after the ruling of the District Court in the Meiliana case (referred to in section 5 (i)), "Indonesia's Ministry of Religious Affairs ... issued a circular on "azan" with guidelines on when and how it ought to be broadcast by mosques ... Titled "The use of loudspeakers in mosques, langgar and musholla' [Indonesian terms for prayer houses], the circular ... urges the religious institutions to follow the instructions of the director-general of Muslim guidance". For details on the Ministry's six-point instructions see (The Straits Times (Singapore)). In summary, the guidelines consist of six points and pertain to the maintenance of loudspeakers; muezzins and the quality of their voices; sound levels during prayers; the broadcasting of other noises; qualities of the adhan; and the appropriate timing of adhans.

Ulama in Pakistan anticipated that, once introduced, an amplified adhan may be perceived as "noise". Thus, although the 1965 Loudspeaker Ordinance regulating loudspeakers exempts amplified adhans, it does so subject to the proviso that it be rendered in a "moderate tone". See (Khan 2011, p. 582).

Following complaints received about the use of amplified adhans in Singapore where Muslims are a minority and "[af]ter discussions with the government, Islamic organizations agreed to (1) reduce the amplitude of loudspeakers in existing mosques, where they remain facing outside, (2) re-direct loudspeakers toward the interior of new mosques to be built in the future and (3) broadcast the call to prayer five times a day over the radio." (Lee 1999, p. 91).

Para. 17 of the Ellaurie case.

Q.4:36. The English translation is based on (Yusuf Ali 1946).

(Sahih Al-Bukhārī 1997, vol. 8, p. 234 (Book 81, chp. 3, Hadith 6416)).

See (South African Muslim Network (SAMNET)).

(Renteln 2014, pp. 389-90).

See (Mokgoro 1998, p. 2).

See Minister of Home Affairs and Another v Fourie and Another (CCT 60/04) [2005] ZACC 19; 2006 (3) BCLR 355 (CC); 2006 (1) SA 524 (CC) (1 December 2005) at Para. 60. Emphasis added.

\section{References}

\section{Primary Source}

Afzal Ansari and 2 Others vs. State of U.P. And 2 Others PUBLIC INTEREST LITIGATION (PIL) No. 570 of 2020.

Ali, Abdullah Yusuf. 1946. The Holy Qur'an (Text, Translation and Commentary). Jeddah: Islamic Education Centre.

Allaclas Investments (Pty) Ltd. v Milnerton Golf Club (Stelzner and others Intervening) 2007 (2) SA 40 (C).

Allaclas Investments (Pty) Ltd. \& Another v Milnerton Golf Club \& Others [2007] 167 SCA (RSA).

Applicant's Heads of Argument, 29 July 2020.

Applicant's Evidence of Call to Prayer at the Madrasah property: http://mlnr.org/C2P/DurbanHighCourt.Case3848of2019.C2PVideo. mp4, accessed on 7 March 2021, available in Applicant's Heads of Argument, 2020, pp. 5, 13.

Assagay Quarries (Pty) Ltd. v Hobbs 1960 (4) SA 237 (N).

Cape Town, South Africa: Streets, Public Places and the Prevention of Noise Nuisances By-law. 2007. Available online: https: / / openbylaws.org.za/za-cpt/act/by-law/2007/streets-public-places-noise-nuisances/eng/ (accessed on 18 March 2021).

Christian Education South Africa v Minister of Education (CCT4/00) [2000] ZACC 11; 2000 (4) SA 757; 2000 (10) BCLR 1051 (18 August 2000).

Church of God (Full Gospel) in India v. K.K.R. Majestic Colony Welfare Association AIR 2000 SC 2773.

City of Tshwane: Noise Pollution. 2020. Available online: http:/ /www.tshwane.gov.za/sites/Departments/Health-Department/ Pages/Noise-Management.aspx (accessed on 18 March 2021). 
City of Tshwane: Noise Management Policy. 2020. Available online: http:/ / www.tshwane.gov.za/sites/Departments/Agricultureand-Environment-Managemental/Noise\%20Management/NoiseAppendixA.pdf (accessed on 18 March 2021).

Constitution of the Republic of South Africa, Act 200 of 1993.

Constitution of the Republic of South Africa, 1996.

De Charmoy v Day Star Hatchery (Pty) Ltd. 1967 (4) SA 188 (D).

Director of Public Prosecutions, Transvaal v Minister for Justice and Constitutional Development and Others (CCT 36/08) [2009] ZACC 8; 2009 (4) SA 222 (CC); 2009 (2) SACR 130 (CC); 2009 (7) BCLR 637 (CC) (1 April 2009).

Ellaurie v Madrasah Taleemuddeen Islamic Institute and Another [Case Number] (3848/2019) [2020] ZAKZDHC [The High Court of South Africa Kwazulu-Natal Local Division, Durban] 32 (21 August 2020). A transcript of the case is available at http://www.saflii.org/ $\mathrm{za} /$ cases/ZAKZDHC/2020/32.html (accessed on 18 March 2021).

Environment Conservation Act 73 of 1989.

eThekwini, South Africa: Nuisances and Behaviour in Public Places By-law. 2015. Available online: https:/ / openbylaws.org.za/zaeth/act/by-law/2015/nuisances-behaviour-public-places/eng/ (accessed on 18 March 2021).

First Respondents' [Patel, Mohammed Illyas] Opposing Affidavit, set down 29 August 2019.

Founding Affidavit of Chandra.G Ellaurie, 14 May 2019.

Garden Cities Incorporated Association Not For Gain v Northpine Islamic Society 1999 (2) SA 268 (C).

Gien v Gien 19792 SA 1113 (T).

Group Areas Act No.41 of 1950.

International Covenant on Civil and Political Rights (ICCPR) of 1966.

MEC for Education: Kwazulu-Natal and Others v Pillay (CCT 51/06) [2007] ZACC 21; 2008 (1) SA 474 (CC); 2008 (2) BCLR 99 (CC) (5 October 2007).

Minister of Home Affairs and Another v Fourie and Another (CCT 60/04) [2005] ZACC 19; 2006 (3) BCLR 355 (CC); 2006 (1) SA 524 (CC) (1 December 2005).

Moulana Mufti Syed Md. Noorur... vs. State of West Bengal and Ors AIR 1999 Cal 15.

National Heritage Resources Act No.25 of 1999.

Noise Control Regulations (G.N. R. 154 of 1992).

Open By-laws South Africa, available at https:/ / openbylaws.org.za/about.html (accessed on 18 March 2021).

Putusan PN MEDAN Nomor [Decision Number] 1612/Pid.B/2018/PN Mdn. Tanggal [date] 4 June 2018-Meiliana (TERDAKWA) [Accused] (District Court);

Putusan PT MEDAN Nomor [Decision Number] 784/PID/2018/PT MDN. Tanggal [date] 25 October 2018 (High Court); and Decision Number 322 K/PID/2019 (decision of Supreme Court).

Prince $v$ President of the Law Society of the Cape of Good Hope (CCT36/00) [2002] ZACC 1; 2002 (2) SA $794 ; 2002$ (3) BCLR 231 (25 January 2002).

Prinsloo v Shaw 1938 AD 570.

S v Lawrence; S v Negal; S v Solberg (CCT38/96, CCT39/96, CCT40/96) [1997] (10) BCLR 1348 (CC).

Sahih Al-Bukhārī. 1997. The Translation of the Meanings of Sahih Al-Bukhari. (Edited by Khan, Muhammad Muhsin) (9 vols.) (Arabic-English), (vol. 8, p. 234 (Book 81: The book of Ar-Riqaq (Softening of the Hearts), chp. 3, Hadith 6416)) and (vol. 1, p. 355 (Book 10: The book of Adhan. chp. 1, Hadith 603-604) and chp. 2, Hadith 605-606)). Riyadh, Saudi Arabia: Darussalam.

South African Human Rights Commission (SAHRC) Mediation Report: “Complaint by Mr. Ellaurie regarding the calls to prayers by Mosques in Isipingo Beach", 1 March 2005.

Statutes of India (Code of Batavia), 1642.

UN Commission on Human Rights, The Siracusa Principles on the Limitation and Derogation Provisions in the International Covenant on Civil and Political Rights, 28 September 1984, E/CN.4/1985/4.

UN Human Rights Committee (HRC), CCPR General Comment No. 22: Article 18 (Freedom of Thought, Conscience or Religion), 30 July 1993, CCPR/C/21/Rev.1/Add.4.

Van Diemen, Anthony. 1642. A. Godsdienst' in Van der Chijs, J.A. 1885. Nederlandsch-Indisch Plakaatboek, 1602-1811, Eerste Deel, 1602-1642, (Batavia:Landsdrukkerij) at pp. 474-75.

\section{Secondary Source}

Al-Haadi Website of Madrasah Taleemuddeen. 2020a. Madrasah Courses. Available online: http://alhaadi.org.za/madrasah-info/22 -madrasah-courses.html (accessed on 18 March 2021).

Al-Haadi Website of Madrasah Taleemuddeen. 2020b. Available online: http:/ / alhaadi.org.za/ (accessed on 18 March 2021).

Amien, Waheeda, Najma Moosa, and Christa Rautenbach. 2018. Religious, Personal and Family Law Systems in South Africa. In Introduction to Legal Pluralism in South Africa, 5th ed. Edited by Christa Rautenbach. Durban: LexisNexis South Africa, pp. 61-76.

Arab, Pooyan Tamimi. 2017. Amplifying Islam in the European Soundscape: Religious Pluralism and Secularism in the Netherlands. New York: Bloomsbury Academic.

Bantom, Kaylynne. 2020. Cries against prayer call. People's Post, September 1.

Chambers, Dave. 2019. Protected forever: Bo-Kaap wins heritage status after four-year fight. Times Live, March 28.

Charles, Marvin. 2020. Museum seeks to have District Six declared a National Heritage Site. Cape Argus, February 11. 
Dangor, Suliman Essop. 1996. Muslim Society and Islamic Architecture. KZ-NIA Journal 22: 2-3.

Davids, Achmat. 1980. The Mosques of the Bo-Kaap. A Social History of Islam at the Cape. Cape Town: S.A. Institute of Arabic and Islamic Research.

De Vos, Pierre, and Warren Freedman, eds. 2021. South African Constitutional Law in Context, 2nd ed. Cape Town: Oxford University Press Southern Africa.

Ellaurie, Chandra G. 2021. Applicant in the Ellaurie case. Personal communication, March 5, 7 and 8.

Hitchcock, Jennifer. 2005. The 5 Pillars of Islam. Verbum 2: 9. Available online: http://fisherpub.sjfc.edu/verbum/vol2/iss2/9 (accessed on 3 May 2021).

Ishmail, Sukaina. 2020. People 'ignorant' of Bo-Kaap's practices say residents after call to prayer complaint. Cape Argus, August 25.

Jamiatul Ulama KwaZulu-Natal, South Africa Website. 2020. Jamiatul Ulama KZN Statement on the Judgement against the Islamic Call to Prayer (Azaan). Available online: https://jamiat.org.za/jamiatul-ulama-kzn-statement-on-the-judgement-against-theislamic-call-to-prayer-azaan/ (accessed on 18 March 2021).

Khan, Naveeda. 2011. The Acoustics of Muslim Striving: Loudspeaker Use in Ritual Practice in Pakistan. Comparative Studies in Society and History 53: 571-94. [CrossRef]

Kotze, Nico. 2013. A community in trouble?: The impact of gentrification on the Bo-Kaap, Cape Town. Urbani Izziv 24: 124-32. [CrossRef]

Larkin, Brian. 2014. Techniques of Inattention: The Mediality of Loudspeakers in Nigeria. Anthropological Quarterly 87: 989-1015. [CrossRef]

Lee, Tong Song. 1999. Technology and the Production of Islamic Space: The Call to Prayer in Singapore. Ethnomusicology 43: 86-100. [CrossRef]

Lutchman, Chanelle, and Charlene Somduth. 2020. Azaan muffled again High court judgment echoes in Tshwane. The Post, September 9.

Lutchman, Chanelle. 2021. Judge dismisses Isipingo mosque's appeal; call for prayer should not be heard beyond the boundaries of the madrasa. The Post, April 26.

Mahida, Ebrahim Mahomed. 1993. History of Muslims in South Africa: A Chronology. Durban: Arabic Study Circle.

Majiet, Fuad. 2020. Author of forthcoming book on Zeenatul Islam (Muir Street) Mosque. Personal communication, December 30.

Mandela, Zwelivelile Mandla. 2019. How can you suggest that Muir Street Mosque's call to prayer is noise? Cape Argus, May 14.

Masjids/Islamic Centres in South Africa. 2021. Muslim Directory. Available online: https://www.muslim.co.za/masjids (accessed on 18 March 2021).

Mayat, Aslam. 2020. Instructing attorney for the Madrassa in the Ellaurie case (High Court). Personal communication, December 2.

Merriam-Webster. 2021. Definition of madrassa. Available online: https:/ /www.merriam-webster.com/dictionary/madrassa (accessed on 18 March 2021).

Mitchley, Alex. 2020. City of Tshwane tells mosque to stop 'noise pollution' after complaints. News24, September 2.

Mohamed, Hussain. 2020a. District Six mosque turns 100. Southern Suburbs Tatler, April 9.

Mohamed, Hussain. 2020b. Trustee, Zeenatul Islam (Muir Street) Mosque. Personal communication, November 30.

Mokgoro, Yvonne. 1998. Ubuntu and the Law in South Africa. Potchefstroom Electronic Law Journal 1: 1-11. [CrossRef]

Moosa, Najma, and Suleman Dangor. 2019a. Muslim Personal Law in South Africa: Evolution and Future Status. Cape Town: Juta.

Moosa, Najma, and Suleman Dangor. 2019b. An Introduction to Muslim personal law in South Africa: Past to present. In Muslim Personal Law in South Africa: Evolution and Future Status. Edited by Najma Moosa and Suleman Dangor. Cape Town: Juta, chp. 1. pp. 1-25.

Moosa, Najma. 1996. An Analysis of the Human Rights and Gender Consequences of the New South African Constitution and Bill of Rights with Regard to the Recognition and Implementation of Muslim Personal Law (MPL). LL.D. (Legum Doctor) dissertation, University of the Western Cape, Bellville, South Africa. Unpublished.

Moosa, Najma. 2009. South Africa: Indian Law' in Katz, Stanley N (Editor-in-Chief). In The Oxford International Encyclopedia of Legal History. New York: Oxford University Press, vol. 5, pp. 283-84.

Moosa, Najma. 2011. Unveiling the Mind: The Legal Position of Women in Islam-A South African Context, 2nd ed. Cape Town: Juta.

Muhamad, Ebrahim. 2020. Mufti and current representative at the Taleemuddeen Madrassa. Personal communication, December 10.

Muslim Judicial Council (SA) Press Release. 2020. MJC: Amendments to City By-Laws Will Not Affect the Athaan. The MJC Facebook Page. May 14. Available online: https://mjc.org.za/wp-content/uploads/2020/05/1589537914127_Joint-Statement-MJC-CoCTBy-law-amendments-.pdf (accessed on 18 March 2021).

Nurlaelawati, Euis. 2020. UIN, Yogyakarta, Indonesia. Personal communication, November 27.

Onishi, Norimitsu. 2016. Muslim Enclave Forged in Apartheid Now Faces Gentrification. The New York Times, February 29.

Petersen, Thomas. 2019. Spiral of silence. Encyclopedia Britannica. January 2. Available online: https://www.britannica.com/topic/ spiral-of-silence (accessed on 18 March 2021).

Pillay, Taschica. 2020. Prayer call ruling sparks petition. Sunday Tribune, September 6.

Pope, Anne, and Elmien Du Plessis, eds. 2020. The Principles of The Law of Property in South Africa, 2nd ed. Cape Town: Oxford University Press Southern Africa.

Press Council South Africa. 2020. Chandra G. Ellaurie vs. Sunday Times. September 30. Available online: https://www.presscouncil. org.za/Ruling/View/chandra-g-ellaurie-vs-sunday-times--4497 (accessed on 18 March 2021). 
Renteln, Alison Dundes. 2014. The Tension between Religious Freedom and Noise Law-The Call to Prayer in a Multicultural Society. In Religion and Human Rights Discourse. Edited by Hanoch Dagan, Shahar Lifshitz and Yedidia Z. Stern. Jerusalem: The Israel Democracy Institute, pp. 375-411.

Scharnick-Udemans, Lee-Shae Salma. 2019. Mosque's call to prayer controversy show crack in rainbow nation myth. Cape Argus, May 17.

Schirrmacher, Thomas. 2015. The use of loudspeakers for the Islamic call to prayer-An infringement upon negative religious' freedom? International Journal for Religious Freedom (IJRF) 8: 7-14.

South African Muslim Network (SAMNET). 2020. Religious Intolerance-Banning the Call to Prayer. Durban: SAMNET, September 17.

South Durban Basin. 2020. Case Study: Urban Regeneration Initiatives in Isipingo. Available online: http://www.mile.org.za/ Come_Learn/Knowledge_Management/Multimedia\%20Library/ABM\%20Experiences\%20Book/Isipingo\%20Case\%20studyPublication.pdf (accessed on 18 March 2021).

Statistics South Africa. 2015. General Household Survey. 2015. In Statistics South Africa, Statistical Release P0318. Available online: https: / / www.statssa.gov.za/publications/P0318/P03182015.pdf (accessed on 18 March 2021).

Statistics South Africa. 2020. Mid-year population estimates. In Statistics South Africa Media Release; July 9. Available online: http: / / www.statssa.gov.za/?p=13453 (accessed on 18 March 2021).

Sunni Jamiatul Ulama South Africa (SJUSA). 2020. Objection to Silencing of the Adhaan. Facebook Page. August 25. Available online: https: / www.facebook.com/864654886938955/posts/objection-to-silencing-of-the-adhaanthe-sunni-jamiatul-ulamasouth-africa-voices/4302024036535339/ (accessed on 18 March 2021).

The Guardian. 2015. Indonesia bids to muffle noisy mosques. The Guardian, June 25.

The Straits Times (Singapore). 2018. Indonesia issues guidelines on call to prayer. The Straits Times (Singapore), August 26.

Swart, Mia. 2020. 'Too loud': S Africa court bans call to prayer at Durban mosque. Al Jazeera News, August 28.

Van Coller, Helena. 2020. South African high court prohibits Muslim call to prayer. Why it got it wrong. The Conversation, October 12.

Van der Schyff, Gerhard. 2002. Limitation and Waiver of the Right to Freedom of Religion: Garden Cities Incorporated Association Not For Gain v Northpine Islamic Society. 1999 2 SA 268 (C). Journal of South African Law 2: 376-81.

Van der Walt, Andries Johannes, and Gerrit Pienaar. 2016. Introduction to the Law of Property, 7th ed. Cape Town: Juta and Company [Pty] Ltd.

VOC News. 2020. Bo Kaap athaan complaint prompts anger over city's by-laws. VOC News, August 26.

Weiner, Isaac. 2014. Religion Out Loud: Religious Sound, Public Space, and American Pluralism. New York: NYU Press.

Zeidan, Adam. n.d. Encyclopaedia Britannica, Adhān. Available online: https://www.britannica.com/topic/adhan (accessed on 18 March 2021). 